\title{
MELACAK SUMBER DAN KEOTENTIKAN PENAFSIRAN MUQĀTIL BIN SULAYMĀN TENTANG AYAT KISAH PENYALIBAN DAN DIANGKATNYA NABI 'ĪSĀ KE LANGIT
}

\author{
Ahmad Jauhari Umam \\ Muhadarah Al-Anwar 3 \\ Jauhariumam300@gmail.com
}

\begin{abstract}
This article examines the interpretation of the Qur'an about the story of the crucifixion and the lifting of the Prophet 'İsā to the sky in Tafsīr Muqātil bin Sulaymān with a focus on the study of tracing the source of interpretation and its authenticity in surah Āli Imrān verses 54-55 and surah al-Nisā' verse 157- 158. The choice of Muqātil bin Sulayman as a research subject is because he is a controversial one among the Muhaddithīn of his doubtful credibility. In his interpretation Muqātil does not mention sanad and commentary related to history so this needs to be examined in depth. However, the superiority of Muqātil in its interpretation is that it is able to tell the story in the al-Qur'an in detail such the story of the prophet Isa. From the results of this study, it can be concluded that Muqātil bin Sulayman explained that the man crucified by the Jews was not 'İsa but the person who was identic to him named Yahūzā, while' İsa was purified by Allah from the Jews by lifting him up to the sky of the earth from Bait al-Maqdis on night of Lailatu al-Qadr in Ramadhan at the age of thirty-three years. Overall Muqātil did not clearly state the sources of its interpretation, and after going through the process of tracing and muqaranah from the literature of other books, eight narrations are found. By using the theory of Takhrij Hadith and the theory of al-Așil wa al-Dakhīl fì al-Tafsir, the writer found that from the eight narrations, six were categorized as al-Așil fi al-Tafsir and two were categorized as al-Dakhïl fi al-Tafsir.
\end{abstract}

Keywords: validity, source of Riwāyat, the story of the Prophet Isā, Tafsir Muqātil bin Sulaymān

\begin{abstract}
Abstrak
Artikel ini mengkaji penafsiran al-Qur'an tentang kisah penyaliban dan diangkatnya Nabi 'Īsā ke langit dalam Tafsīr Muqātil bin Sulaymān dengan fokus kajian pada pelacakan sumber penafsiran dan keotentikannya dalam surah Āli Imrān ayat 54-55 dan surah al-Nisā' ayat 157-158. Pemilihan Muqātil bin Sulayman sebagai subjek penelitian karena ia termasuk seorang yang kontroversial dikalangan para muḥaddithīn karena diragukan kredibilitasnya. Di dalam tafsirnya Muqātil tidak menyebutkan sanad dan ulasan berkaitan dengan riwayat sehingga hal ini perlu diteliti secara mendalam. Akan tetapi, tafsir ini memiliki kelebihan mampu menceritakan kisah dalam al-Qur'an secara detail, termasuk kisah nabi Isa. Penelitian ini menyimpulkan bahwa Muqātil bin Sulayman menjelaskan bahwa yang disalib oleh kaum Yahudi bukanlah 'Īsa akan tetapi orang yang diserupakan dengannya yang bernama Yahūzāa, sedangkan 'Īsa disucikan dari kaum Yahudi dengan cara diangkat oleh Allah ke langit dunia dari Bait al-Maqdis pada malam Lailatu al-Qadr bulan Ramadhan diusia tiga puluh tiga tahun. Secara keseluruhan Muqātil tidak menyebutkan sumber-sumber penafsirannya secara jelas, dan setelah melalui proses pelacakan dan muqāranah dari literatur kitab lain ditemukan delapan riwayat. Dengan menggunakan pendekatan takhrij hadith dan al-așil wa al-dakhīl fì al-tafsir penulis menemukan dari delapan riwayat tersebut enam masuk kategori al-așil fì al-tafsir
\end{abstract}


(sesuatu yang asli dalam penafsiran)dan dua masuk kategori al-dakhïl fì al-tafsir (sesuatu yang dimasukkan).

Kata Kunci : validitas, sumber riwāyat, kisah Nabi 'Īsā, Tafsir Muqātil bin Sulaymān

\section{A. Pendahuluan}

Dalam menyampaikan pesan ilahi, al-Qur'an menggunakan gaya bahasa maupun metode yang berbeda-beda, diantaranya dengan cara berdialog, membuat berbagai perumpamaan dan melalui kisah-kisah. ${ }^{1}$ Kisah dalam al-Qur'an maksudnya adalah beritaberita al-Qur'an tentang hal ihwāl orang-orang terdahulu, baik umat maupun para nabi yang telah lampau, yang memuat pelajaran dan dapat diambil i'tibār bagi generasi yang datang setelahnya. ${ }^{2}$ Banyak kisah nabi dalam al-Qur'an. Salah satu kisah anbiya ' yang menjadi pembicaraan yang tidak pernah habis hingga saat ini adalah kisah Nabi 'İsa ${ }^{3}$. Kisah Nabi 'Īsa berbeda dengan kisah-kisah nabi lainnya. Nabi 'Īsa memiliki kedudukan yang sangat penting dalam doktrin tiga agama yakni Yahudi, Nasrani dan Islam. ${ }^{4}$

Topik yang paling sering diperbincangkan dari kisah Nabi 'Īsa hingga saat ini adalah mengenai penyaliban dan diangkatnya Nabi 'Īsa ke langit. Menyikapi hal ini, ulama' memiliki pandangan yang berbeda dan bertolak belakang. Ada yang mengatakan yang disalib adalah 'İsa dan ada yang mengatakan bahwa yang disalib hanyalah orang yang diserupakan dengan 'Īsa. Al-Ṭabarī dalam Jāmi' al-Bayān fì Ta'wīl al-Qur'ān menerangkan berbagai pendapat mengenai siapa orang yang disalib. Pertama, yang diserupakan adalah salah satu dari Hawāriyyīn (tanpa menyebutkan siapa yang disalib). Kedua, salah satu dari Hawāriyyīn yang bernama Sirjis. Ketiga, yang disalib adalah Dawud. ${ }^{5}$ Sedangkan Fakhruddin al-Rāzī menyebutkan bahwa orang yang disalib itu bernama Tayțāyūs. ${ }^{6}$ Ibn Abbās menyebutnya Tityānus. ${ }^{7}$ Penulis melihat perbedaan pendapat tentang siapakah orang yang disalib inilah menjadi isu yang menarik untuk dikaji lebih lanjut.

\footnotetext{
${ }^{1}$ Nadirsyah Hosen, Tafsir Al-Qur'an di Medsos (Yogyakarta: Bunyan, 2017), hlm. 223.

${ }^{2}$ Muhammad Hadi Ma'rifat, Kisah-Kisah Al-Qur'an Antara Fakta dan Metafora terj. Azam Bahtiar (t.tp: Citra, 2013), hlm. 28.

${ }^{3}$ Al-Qur'an sendiri menyebut lafal 'Īsā sebanyak 21 kali, dengan sebutan al-Masīh sebanyak 11 kali dan sebutan Ibnu Maryam sebanyak 23 kali. Lihat Riqza Ahmad, Mind Map Al-Qur'an \& Ulum Al-Qur'an (Kudus: Mubarokatan Thoyyibah, 2019), hlm. 198.

${ }^{4}$ Muhammad Nasyirudin, "Kematian dan Penyaliban Nabi Isa AS dalam Tafsir Al-Manar" (Skripsi di UIN Sunan Kalijaga, 2016), hlm. 2-3.

${ }^{5}$ Muhammad bin Jarīr al-Ṭabarī, Jāmi' al-Bayān fì Ta'wīl al-Qur'an, vol. 9 (t.tp: Mu'assasah al-Risalah, 2000), hlm. 367-372.

${ }^{6}$ Abū Abdullah Fakruddin al-Rāzī, Mafātīh al-Ghaybi, vol. 9 (Beirut: Dar Ihya' Turath, 1999), hlm. 261.

${ }^{7}$ Abdullah Ibn Abbās dikumpulkan oleh Muhammad bin Ya'qūb al-Fairūzābad̄̄, Tanwīr al-Miqbās min Tafsir Ibn Abbās (Beirut: Dar al-Kutub al-Ilmiyah, t.th ), hlm. 85.
} 
Melacak Sumber dan Keotentikan Penafsiran Muqātil bin Sulaymān

Ahmad Jauhari Umam

Doi: doi.org/10.47454/itqan.v5i1.710

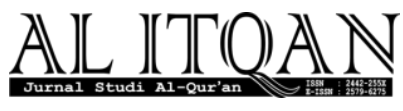

Muqātil bin Sulaymān (w.150 H), termasuk tokoh tafsir generasi tābi'it-tābi'înn. ${ }^{8}$ Muqātil bin Sulaymān (selanjutnya disebut Muqātil) merupakan sosok yang kontroversial, tidak sedikit ulama' yang meragukan kredibilitasnya. Muqātil dianggap sebagai anthrophomorphis (mujassimah) ${ }^{9}$. Di kalangan ilmuan hadis banyak ulama' yang menilai hadis-hadis yang diriwayatkan Muqātil merupakan periwayat hadis matrūk, tidak thiqqah. Ia seorang yang kadhīb dan masih banyak penilaian negatif yang lainnya. ${ }^{10}$ Dalam keilmuan tafsir, gaya penafsiran Muqātil juga berbeda dibanding dengan tradisi penafsiran di zamannya. Muqātil dianggap sangat berani mengambil kisah-kisah 'isrā' ’̀liyyāt dan meriwayatkanya tanpa disertai dengan sanad dan tanpa ulasan di dalamnya. Menurut Abdullah Mạ̣mūd Shaḥātah ${ }^{11}$, Tafsir Muqātil banyak bersandar pada hadith-hadith dan athar yang daîf. Akan tetapi jika dilakukan muqāranah dengan literatur kitab lainnya maka riwayat tersebut tampak tidak daĭf. $^{12}$

Muqātil memiliki kitab tafsir yang ia tulis sendiri. Nama tafsirnya yang dinisbatkan kepadanya yaitu Tafsir Muqātil bin Sulaymān, dianggap sebagai kitab tafsir pertama sempurna 30 juz yang sampai kepada kita. Hal yang menjadikan Tafsir Muqātil bin Sulaymān sebagai objek utama dalam penelitian ini dilatarbelakangi karena Tafsir Muqātil bin Sulaymān memiliki pendekatan yang berbeda saat menafsirkan suatu ayat al-Qur'an. Teks setiap surah diperlakukan sebagai suatu cerita yang berkesinambungan. Termasuk sumbangan utama Muqātil dalam dunia penafsiran adalah ketika memberikan informasi mengenai pokok bahasan yang dibahas di dalam ayat, terutama dalam uraiannya mengenai ayat yang bercerita tentang kisah zaman dahulu, Muqātil memberikan uraian yang panjang lebar dalam bentuk cerita tambahan yang menunjukkan bahwa ia mengetahui dengan baik alur cerita-cerita tersebut. $^{13}$

\footnotetext{
${ }^{8} I b i d$., hlm. 234. Lihat juga Muqātil bin Sulaymān, Tafsīr Muqātil bin Sulaymān, vol. 5(Beirut: Mu'assasah alTārikk al-'Arabi, 2002), hlm 24.

${ }^{9}$ Anthrophomorphis menurut KBBI adalah pengenaan ciri-ciri manusia pada selain manusia seperti binatang, tumbuh-tumbuhan, benda mati, termasuk juga Tuhan. Sedangkan mujassimah adalah sebutan bagi orang memiliki pemahaman bahwa Allah adalah jisim, memiliki tangan, wajah dan lain-lain yang serupa dengan makhluknya.

${ }^{10}$ Afrohul Banat dan Siti Amilatus Sholihah, "Pandangan Muqātil bin Sulaymān al-Balkhī (w. 150 H/767 M) tentang Muhkkamāt dan Mutashäbihāt" pada Jurnal Al-Itqān, vol. 3, no. 1, 2017, hlm. 26 dan 29 (https://doi.org/10.47454/itqan.v3i1.32).

${ }^{11}$ Mahmūd Shahāatah adalah pentaḥqūq Tafsir Muqātil bin Sulaymān, Abdullah Mahmūd Shahāătah pada tahun 1966 untuk pertama kalinya menyunting naskah Tafsir Muqātil bin Sulaymān. sejak itu edisinya (empat jilid) diterbitkan oleh Hai'ah al-Kitab al-Amma (1980-1987).

${ }^{12}$ Sulaymān. Tafsìr Muqātil bin Sulaymān, vol. 1, hlm. 125.

${ }^{13}$ Kees Versteegh, "Tafsir Quran Paling Awal: Tafsir Muqātil", (Makalah disampaikan di Universitas Leiden pada 3 November 1988), hlm. 208.
} 
Bagaimana penafsiran Muqātil dan validitas penafsirannya tentang kisah penyaliban dan diangkatnya Nabi Isa? Pertanyaan inilah yang menjadi rumusan masalah dalam artikel ini. Dalam menjawab pertanyaan tersebut, penulis melakukan analisis-kritis dengan menggunakan teori Takhrïj Hadith sebagai alat untuk melacak sumber penafsiran yang berkaitan dengan periwayatan dan teori al-Așil wa al-Dakhīl fi al-Tafsir untuk penggalian otentisitas sumber penafsiran tersebut. Dengan melihat lebih jauh mengenai kisah nabi Isa melalui tafsir Muqātil sekaligus menelusuri otentisitas sumbernya, diharapkan artikel ini dapat menambah khazanah pengetahuan yang lebih luas dan lebih valid daripada versi yang selama ini diperdebatkan oleh 3 agama besar sekaligus yaitu Islam, Nasrani dan Yahudi.

\section{B. Biografi Muqātil bin Sulaymān}

\section{Riwayat Hidup Muqātil bin Sulaymān}

Nama lengkapnya adalah Abū al-Ḥasan Muqātil bin Sulaymān bin Bashīr al-Bulkhī. ${ }^{14}$ Ia dijuluki sebagai kabīr al-mufassirin, ${ }^{15}$ dan șāhibu al-tafsìr ${ }^{16}$ Muqātil merupakan salah satu ulama ahli tafsir generasi ketiga kaum muslimin (Atbā' al-Tābi'̄nn). Pendapat yang kuat mengatakan Muqātil lahir tahun $80 \mathrm{H} \cdot{ }^{17} \mathrm{Hal}$ ini didasari bahwa Muqātil memiliki kedekatan dengan Sālim bin Aḥwaz al-Mazīn̄e, utusan dari khalifah terakhir Bani Umayyah, Nasr bin Sayyār (w. $131 \mathrm{H}$ ) di Khurasan. Ketika itu Muqātil berumur 40 tahun sehingga kemungkinan Muqātil lahir tahun $80 \mathrm{H}^{18}$

Muqātil lahir dan tumbuh di Balkh yang merupakan salah satu daerah di wilayah Khurasān. Masa hidup Muqatil setelahnya dihabiskan di beberapa daerah di Irak. Kota pertama yang menjadi tujuannya adalah Bașrah, kemudian ia memasuki Baghdad. Pada masa berikutnya ia kembali lagi ke Baṣrah hingga ia wafat pada tahun $150 \mathrm{H}^{19}$

\section{Jejak Intelektual Muqātil bin Sulaymān}

\footnotetext{
${ }^{14}$ Muqātil bin Sulaymān. Tafsīr Muqātil bin Sulaymān, vol. 5, hlm. 23.

${ }^{15}$ Muhammad bin Ahmad bin Uthmān bin Qaymāz al-Dhahāb̄̄, Siyaru A 'lāmi al-Nubalā', vol. 7 (t.tp: Muassasah al-Risalah, 1985), hlm. 202.

${ }^{16}$ Jamāluddin bin al-Zakī Abī Muhammad al-Qaḍā'̄̄ al-Mizz̄î, Tahdhīb al-Kamāl fì Asmāi al-Rijāl, vol. 28 (Beirut: Mua'assasah al-Risalah), hlm. 434

${ }^{17}$ Sulaymān, Tafsīr Muqātil bin Sulaymān, hlm. 28. Lihat juga al-Dhahāb̄̄, Siyaru A'lāmi al-Nubalā', vol. 7, hlm. 203.

${ }^{18}$ Mun'im Sirry. "Muqatil b. Sulaymān and Anthropomorphism”, dalam Jurnal Studia Islamica, vol. 107, no. 1, 2012, hlm. 39-40 (https://doi.org/10.1163/19585705-12341235).

${ }^{19}$ Muqātil bin Sulaymān, al-Wujūh wa al-Naz̄āir fì al-Qur'an al- 'Ażīm, (Riyad: Maktabah al-Rushd, 2011), hlm. 6.
} 
Melacak Sumber dan Keotentikan Penafsiran Muqātil bin Sulaymān

Ahmad Jauhari Umam

Doi: doi.org/10.47454/itqan.v5i1.710

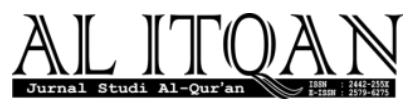

Penulis tidak menemukan literatur yang menerangkan bagaimana perjalanan intelektual Muqātil sejak kecil hingga remaja, hanya ditemukan wilayah dimana Muqātil menimba ilmu. Riḥlah 'ilmiyyah Muqātil dimulai dari kota kelahirannya Balkh, kemudian pindah ke Marw. ${ }^{20}$ Setelah itu, ia beralih ke Irak dan bertempat tinggal di Basrah. Kemudian ia ke Baghdad, dan pada akhirnya ia kembali ke Basrah hingga wafat pada $150 \mathrm{H}^{21}$ Menurut A.H. John, sebelum ke Basrah Muqātil terlebih dulu mampir ke Makkah dan Madinah. ${ }^{22}$

Guru-guru Muqātil diantaranya adalah Thābit al-Bannānī, Sa'īd al-Maqbarī, 'Ațā’ bin Abī Rabbāh, 'Ațiyyah bin Sa'd al-Aufī, Amr bin Shu'ā̄b, Ibn Shihāb al-Zuhrī, Nāfí' Maula Ibn Umar, Zaid bin Aslam, Shurahbil bin Sa'd Maula al-Anșār, Abdullah bin Buraidah, Ubaidillah bin Abī Bakr bin Anas bin Mālik, Muhammad bin Sīrīn, Abī Ishāq al-Sabī’̄̄, Abī al-Zubaīr al-Makkī. ${ }^{23}$ Al-Ḍaḥhāk bin Mazāḥim dan Mujāhid bin Jabr al-Makkī. ${ }^{24}$

Murid-muridnya diantaranya 'Ismā'̄̄l bin 'Iyāsh, Sa'd bin al-Ṣult, Sufyān bin 'Uyainah, Abd al-Raḥmān bin Muhammad al-Hārib̄i, Abd al-Razzāq bin Himām, al-Walīd bin Muslim, Abū Naṣ̄ir Sa'dāl, Ibn Sa’̄̄d al-Bulkhī, Abū Ḥaiwah Shuraīh bin Barīd al-Ḥumṣī, Abū Nașr Manșūr bin Abd al-Ḥamīd al-Bāwardhī, Abū al-Junaīd al-Ḍarīr, Abū Yahyā alḤaman̄̄, Baqiyyah bin al-Walīd, Shabābah bin Suwār, 'Imād bin Qīrāṭ al-Naisābūrī, Abdullah bin al-Mubārak, Abd al-Rahman bin Sulaymān, Abd al-Șamad bin Abd al-Wārith, 'Utāb bin Muhammad bin Shūdhb, 'Alī bin al-Ju'd, 'Īsā bin Abī Fatimah, 'Īsā bin Yūnus, Harmī bin 'Imārah bin Abī Ḥanīfah, Ḥammād bin Muhammad al-Nawārī, Ḥamzah bin Zinād al-Ṭūsī, Naṣr bin Ḥammād al-Warāq, Yaḥyā bin Shabl, Yūsuf bin Khālid, al-Walīd bin Marnad alBairūtî. 25

Muqātil sangat produktif dalam dunia penulisan, Al-Radd 'ala al-Qadariyah merupakan salah satu karyanya dalam bidang teologi untuk menanggapi perdebatannya dengan Jahm bin Șafwān. Karya lainnya lebih banyak pada bidang tafsir dan ulum al-Qur'an. Beberapa karya yang dihasilkan adalah al-Tafsīr al-Kabìr (merupakan nama lain dari Tafsir Muqātil bin Sulaymān), Nawādir al-Tafsīr, Al-Nāsikh wa al-Mansūkh, Al-Wujūh wa al-Nazāir fì al-Qur'an al-'Az̄im, Tafsir Khamsimiah Āyat min al-Qur'an al-Karìm, Al-Aqsām wa al-

\footnotetext{
${ }^{20}$ Marw merupakan salahsatu daerah di Khurasan, berjarak 122 farsakh dari Bulkh dan dari Naisabur 70 farsakh (1 farsakh setara kurang lebih $5 \mathrm{Km}$ ). lihat Sulaymān, Tafsìr Muqātil bin Sulaymān, vol. 5, hlm. 32.

${ }^{21}$ Ibid., hlm. $29-33$.

${ }^{22}$ A.H. Johns, "Muqatil B. Sulayman", dalam Oliver Leaman (ed.), The Qur'an: an Encyclopedia, (London dan New York: Routledge, 2006), hlm. 428.

${ }^{23}$ Sulaymān, Tafsìr Muqātil bin Sulaymān, hlm. 48.

${ }^{24}$ Al-Mizzī, Tahdhīb al-Kamāl fì Asmāi al-Rijāl, hlm. 434-435.

${ }^{25}$ Ibid., hlm. 49-50.
} 


\section{Al] $]\left[\cap(\Omega)\right.$ A N $\mathbb{N} \| \begin{array}{l}\text { Melacak Sumber dan Keotentikan Penafsiran Muqātil bin Sulaymān } \\ \text { Ahmad Jauhari Umam }\end{array}$ \\ Doi: doi.org/10.47454/itqan.v5i1. 710}

Lughāt, Al-Āyāt al-Mutashābihāt, ${ }^{26}$ Al-Taqdīm wa al-Ta 'khīr, Al-Jawābāt fì al-Qur'an, dan Al-Qirā 'àt. ${ }^{27}$

\section{Pandangan Ulama' tentang Muqātil bin Sulaymān dan Tafsirnya}

Mengenai pendapat ulama' tentang status Muqātil bin Sulaymān ada yang memujinya dan banyak pula yang mencelanya. Ḥusaīn al-Dhahabī mengatakan bahwa kejelekan Muqātil lebih banyak daripada kebaikannya, dan kerusakannya lebih besar daripada manfaatnya. ${ }^{28}$ Diantara riwayat atau pendapat yang memujinya adalah:

Diriwayatkan dari Rabī’ bin Sulaymān bahwa ia mendengar al-Shāfi'̄̄ berkata, "Barangsiapa yang ingin memahami Tafsir maka belajarlah kepada Muqātil bin Sulaymān" ${ }^{29}$ Ahmad bin Hanbal ditanya tentang sosok Muqātil bin Sulayman kemudian ia menjawab, "Saya berpendapat bahwa kitab-kitabnya berisi ilmu-ilmu tentang al-Qur'an"30

Tidak sedikit pula yang menilai buruk terhadap Muqātil bin Sulaymān, berikut diantaranya:

a. Abū Mu'āẓ al-Naḥwī mengatakan bahwa Muqātil bin Sulaymān adalah seorang yang fāsiq dan fäjir (keji). ${ }^{31}$

b. Abū Dawūd mengatakan tarakū hadīthuhu. 'Amr bin 'Alī mengatakan Matrūk al-Hadīth, Kadhdhāb. Al-Bukhārī mengatakan ia adalah munkar al-Hadīth, sakatū 'anhu. Abū Ḥātim mengatakan Matrūk al-Hadìth. Al-Nasā'ī mengatakan Kadhdhāb. ${ }^{32}$

c. Abū Ḥātim bin Ḥibbān mengatakan Muqātil mengambil dari Yahudi dan Nasrani tentang pemahaman al-Qur'an yang cocok dengan kitabnya mereka dan Muqātil adalah seorang yang mushabbihah (menyerupakan Allah dengan dengan makhluknya), ia seorang pembohong di dalam hadis. ${ }^{33}$

d. Al-Suyūṭī berpendapat bahwa Muqātil bin Sulayman adalah orang yang daîf..$^{34}$

\footnotetext{
${ }^{26}$ Sulaymān, Tafsīr Muqātil bin Sulaymān, vol. 5, hlm. 72.

${ }^{27}$ Sulaymān, al-Wujūh wa al-Nazāir fì al-Qur'an al- 'Aż̄im, hlm.7.

${ }^{28}$ Muhammad Husain al-Dhahabī, al-Tafsìr wa al-Mufassirūn, vol. 3 (Kairo: Dar al-Hadith, 2005), hlm. 10.

${ }^{29}$ Al-Mizzī, Tahdhīb al-Kamāl fì Asmāi al-Rijāl, vol. 28, hlm. 436.

${ }^{30}$ Abū Bakar Ahmad bin 'Alī al-Khațīb al-Baghdādī, Tārīkhu Baghdād, vol. 15 (Beirut: Dar al-Gharbi al-Islami, 2002), hlm. 207.

${ }^{31}$ Al-Mizzī, Tahdhīb al-Kamāl fì Asmāi al-Rijāl, vol. 28, hlm. 443 - 445.

${ }^{32}$ Ahmad bin 'Alī bin Muhammad bin Ahmad bin Hajar al-'Asqalānī, Tahdhīb al-Tahdhīb, vol. 10 (India: Matba'ah Dairah al-Ma'arif al-Nizamiyah, 1905 M), hlm. 283 - 284.

${ }^{33}$ Al-Mizzī, Tahdhīb al-Kamāl fi Asmāi al-Rijāl, vol. 28, hlm. 448.

${ }^{34}$ Jalāluddīn Abd al-Rahman bin Abi Bakar al-Suyūṭị, al-Itqān fì Ulūm al-Qur'an (Beirut: Dar al-Kutub Ilmiyah, 2018), hlm. 590.
} 
Melacak Sumber dan Keotentikan Penafsiran Muqātil bin Sulaymān Ahmad Jauhari Umam

Doi: doi.org/10.47454/itqan.v5i1.710

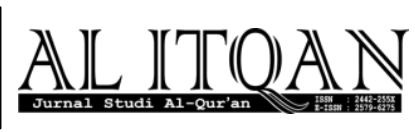

e. Husaīn al-Dhahab̄i berpendapat bahwa Muqātil bin Sulayman hanya meriwayatkan khurafat-khurafat dan penyebar isrā' '̄liyyāt. ${ }^{35}$

\section{Deskripsi Tafsir Muqātil bin Sulaymān}

\section{Latar Belakang Penulisan}

Kitab Tafsir Muqātil bin Sulaymān ini ditulis sendiri oleh Muqātil secara utuh. Tidak ditemukan secara jelas kapan waktu, tujuan dan maksud dari penulisan kitab ini. Hanya tersirat dalam muqaddimah-nya bahwa ia ingin apa yang ia ketahui mengenai al-Qur'an bermanfaat baik bagi umat Islam secara luas maupun pribadinya sendiri. Selain itu, Muqātil ingin umat Islam dalam berinteraksi dengan al-Qur'an tidak hanya berhenti pada fase membaca saja, tetapi juga harus memahami apa yang terkandung dalam al-Qur'an, hal ini tercermin dari perkataannya:

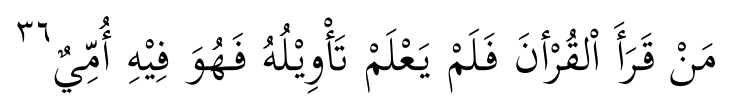

Barang siapa yang membaca al-Qur'an sedang ia tidak mengetahui takwilnya, maka ia dianggap sebagai orang yang ummi (karena kebodohannya)

\section{Metodologi Tafsir Muqātil bin Sulaymān}

Tafsir Muqātil bin Sulaymān dapat dikategorikan sebagai jenis tafsir bi al-Ma'thūr, hal ini disebabkan karena mayoritas sumber-sumber yang digunakannya dalam menafsirkan suatu ayat bersumber dari kutipan-kutipan baik al-Qur'an ${ }^{37}$, Hadith $^{38}$, perkataan sahabat ${ }^{39}$ maupun tabi'in ${ }^{40}$ (tapi memang riwayat-riwayat tersebut tanpa disertai dengan

\footnotetext{
${ }^{35}$ Husain al-Dhahabī, al-Tafsìr wa al-Mufassirūn, vol. 3, hlm.12.

${ }^{36}$ Sulaymān, Tafsīr Muqātil bin Sulaymān, vol. 1, hlm. 27.

${ }^{37}$ Muqātil banyak merujuk keterangan yang bersumber dari al-Qur'an. Salahsatu contoh penafsiran dengan sumber al-Qur'an adalah ketika menafsirkan Q.S al-Fatihah ayat 4

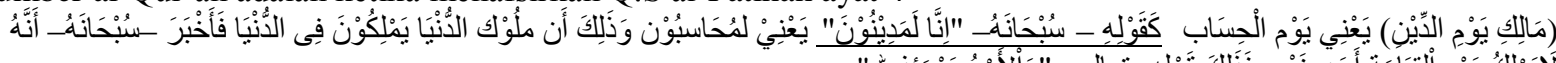

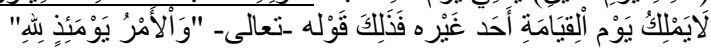

Ia sendiri membagi pemahaman terhadap al-Qur'an menjadi empat macam, yaitu ayat-ayat yang hanya diketahui Allah, pemahaman ayat yang diketahui oleh para ulama', pemahaman ayat yang hanya dipahami oleh orang Arab, dan pemahaman ayat yang bisa dipahami umat secara umum. Lihat Sulaymān, Tafsīr Muqātil bin Sulaymān, vol. 1, hlm. 27.

${ }^{38}$ Seperti saat menafsirkan Q.S al-Nabā' ayat 30:

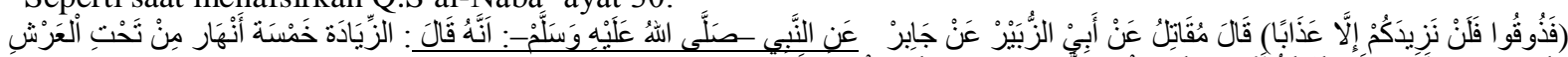

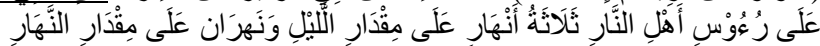

${ }^{39}$ Misalnya ketika menafsirkan surah al-Kahfi ayat 86, Muqấtil mengutip pendapat Ibn Á Á

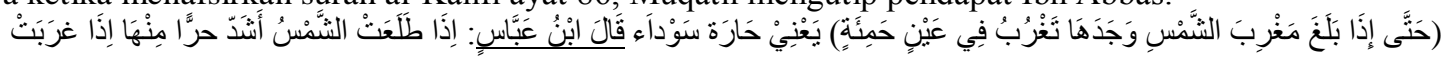

${ }^{40}$ Misalnya saat menafsirkan lafal كنز kepada Tabi'in

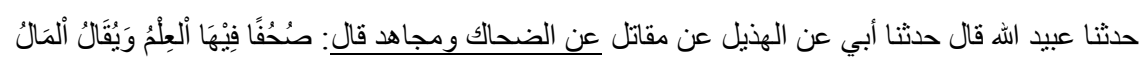


sanad). Dalam menafsirkan ayat al-Qur'an Muqātil menggunakan metode tafsir taḥlīlī yaitu menjelaskan maksud ayat al-Qur'an ditinjau dari berbagai aspek yang dihidangkan secara runtut sesuai urutan ayat dalam mushaf. ${ }^{41}$ Hal ini didasarkan karena dalam praktiknya Muqātil menafsirkan suatu ayat dengan memperhatikan runtutan ayat secara muṣhafi, mengemukakan asbāb al-nuz $\bar{u} l^{42}$, qirā' $\bar{a} t^{43}$, penjelasan makna kata, menyebutkan riwayat pada nabi, sahabat dan tabi'in. Menurut hemat penulis Tafsir Muqātil bin Sulaymān lebih condong ke dalam corak historis (sejarah). Hal ini dikarenakan ketika menafsirkan ayat-ayat yang menerangkan tentang kisah atau sejarah masa lampau Muqātil memberikan porsi yang lebih banyak daripada saat menafsirkan ayat-ayat yang berbicara tema lainnya seperti ayat tentang hukum, tasawuf, sosial kemasyarakatan dan lainnya.

Tafsir Muqātil bin Sulaymān pertama kali di tahqūq oleh Abdullah Maḥmūd Shahatah pada tahun 1966 M dan diterbitkan oleh Hai'at al-'Āmma di Kairo dalam empat jilid. ${ }^{44}$ Maḥmūd Shahatah menggunakan beberapa naskah (manuskrip) saat men-tahqīq kitab ini. Naskah tersebut adalah:

a. Naskah Ahmad al-Thālith (cirinya dirumuskan dengan huruf hamzah) naskah ini berisi lengkap seluruh al-Qur'an yang ditulis tahun $886 \mathrm{H}$,

a. Naskah Faīḍ Allah (cirinya dirumuskan dengan huruf fa') naskah ini hanya berisi separuh akhir dari al-Qur'an yang ditulis tahun $524 \mathrm{H}$,

b. Naskah al-Azhariyah (cirinya dirumuskan dengan huruf Za') naskah ini berisi mulai dari surah Maryam sampai surah Fușșilat yang ditulis tahun Abad IV H,

c. Naskah Umānah (cirinya dirumuskan dengan huruf mim) naskah ini berisi seluruh alQur'an yang ditulis tahun $1165 \mathrm{H}^{45}$

d. Naskah Qypriliu (cirinya dirumuskan dengan huruf lam) naskah ini ditulis abad VI H,

\footnotetext{
${ }^{41}$ M Quraish Shihab, Kaidah Tafsir (Tangerang: Lentera Hati, 2013), hlm. 378.

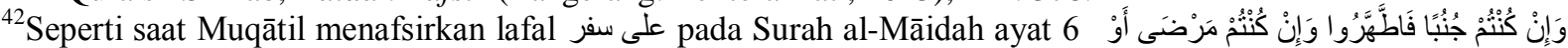
(عَلى سَفَر نزلت فى عائشة ـرضي الله عنها- حين أسفطت قلادتها وهي مع النبي -صلى الله عليه وسلم- فى غزاة بلني أنمار و هم حى من قيس عيلان. ${ }^{43}$ Muqatil menggunakan qirā' ât sebagai sumber penafsiran merujuk kepada qirā'āt sahabat seperti Abdullah Ibn Mas'ūd, dan Ubay bin Ka'ab. Seperti ketika ia menafsirkan Q.S al-Baqarah ayat 234

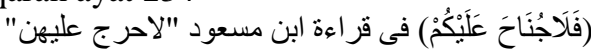

${ }^{44}$ Dalam penelitian ini penulis menggunakan Tafsir Muqātil bin Sulaymān yang ditahqūq Abdullah Maḥmūd Shahatah cetakan tahun 2002 oleh penerbit Mu'assasah al-Tārïkh al-'Arabi terdiri dari lima jilid.

${ }^{45}$ Sulaymān, Tafsīr Muqātil bin Sulaymān, hlm. 1. Keempat naskah awal tersebut tersimpan di tempat penyimpanan manuskrip Universitas Kerajaan Arab di Kairo.
} 
Melacak Sumber dan Keotentikan Penafsiran Muqātil bin Sulaymān Ahmad Jauhari Umam

Doi: doi.org/10.47454/itqan.v5i1.710

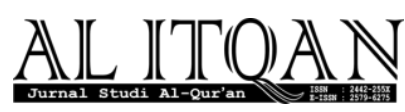

e. Naskah Hamīdiyah (cirinya dirumuskan dengan huruf ha') naskah ini ditulis pada tahun XIII $\mathrm{H}^{46}$

Karena tidak semua naskah tersebut berisi lengkap seluruh al-Qur'an, Mạ̣mūd Shahatah mengkombinasinya menjadi satu dengan rincian separuh awal al-Qur'an menggunakan dua naskah primer yakni naskah Ahmad al-Thālith dan naskah Qypriliu, dan dua naskah sekunder yakni naskah Umānah dan naskah Ḥamīdiyah. Sedangkan separuh akhir dari al-Qur'an menggunakan naskah Faīḍ Allah dan naskah al-Azhariyah. ${ }^{47}$

Dalam penulisan kitab tafsirnya, Muqātil menggunakan sistematika muṣhafì yaitu penyusunan kitab tafsir dengan berpedoman pada susunan (tartib) ayat-ayat dan surah-surah dalam mushafrasm uthman̄̄, dengan dimulai dari surat al-Fātihah sampai al-Nās. Adapun langkah metodologis yang dilakukan Muqātil dalam kitab tafsirnya sebagai berikut; pertama, menyebutkan nama surah, kemudian mencantumkan informasi jumlah ayat dan klasifikasi Makkī-Madanī didalam bingkai hiasan. kedua, menyebutkan keseluruhan ayat secara lengkap dalam satu surat diawali dengan basmalah kecuali surah al-Taubah, yang dibingkai dengan hiasan sederhana, namun dibagian awal surah hiasanya agak berbeda hiasanya. Ketiga, menyebutkan Makkī-Madanī, jumlah ayat yang diawali dengan nama surat,kemudian secara global menjelaskan sejarah turunnya suatu surah, kandungan dan tujuan suatu surat. Keempat, melakukan penafsiran dengan diawali lafal basmalah. Ketika akan melakukan penafsiran, sebelum menyebutkan awal ayat didahului dengan kalimat قوله سبحانه- قال سبحانه atau Lafal ayat terdapat dalam kurung dan penafsirannya diluar kurung. Dan ketika akan menerangkan asbāb al-nuzūl ayat tertentu biasanya didahului lafal نزلت فى... dan ketika menerangkan

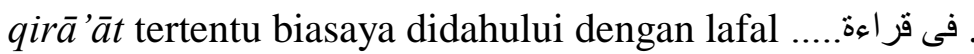

Kitab Tafsīr Muqātil bin Sulaymān ini terdiri dari lima jilid, setiap jilid berisi seperempat al-Qur'an dan satu jilid terakhir berisi ulasan pentahqīq. Adapun sistematika secara sederhana dapat dipetakan sebagai berikut:

\begin{tabular}{|c|c|c|}
\hline Jilid & Jumlah Halaman & Rincian Isi \\
\hline Jilid 1 & 601 halaman & $\begin{array}{l}\text { Muqaddimah pentahqūq (Abdullah Mahmūd } \\
\text { Shahatah), muqaddimah pengarang (Muqātil bin } \\
\text { Sulaymān), pembahasan tentang naskah kuno terkait } \\
\text { dengan Tafsir Muqātil bin Sulaymān, berisi tafsir Q.S }\end{array}$ \\
\hline
\end{tabular}

\footnotetext{
${ }^{46}$ Ibid., hlm. 1. Kedua naskah terakhir tersebut tersimpan di Turki.

${ }^{47}$ Ibid., hlm. 1.
} 


\begin{tabular}{|c|c|c|}
\hline & \multicolumn{2}{|c|}{$\begin{array}{l}\text { Melacak Sumber dan Keotentikan Penafsiran Muqātil bin Sulaymān } \\
\text { Ahmad Jauhari Umam } \\
\text { Doi: doi.org/10.47454/itqan.v5i1. } 710\end{array}$} \\
\hline & & al-Fatihah sampai Q.S al-An’ām. \\
\hline Jilid 2 & 790 halaman & Berisi tafsir Q.S al-A’rāf sampai Q.S Maryam \\
\hline Jilid 3 & 956 halaman & Berisi tafsir Q.S Ṭāhā sampai Q.S al-Jāthiyah \\
\hline Jilid 4 & 1065 halaman & Berisi tafsir Q.S al-Aḥqāf sampai Q.S al-Nās \\
\hline Jilid 5 & 379 halaman & $\begin{array}{l}\text { Bagian awal berisi biografi Muqātil bin Sulaymān, } \\
\text { bagian kedua mengenai metode penafsiran Muqātil bin } \\
\text { Sulaymān dan terakhir khātimah }\end{array}$ \\
\hline
\end{tabular}

Daftar isi kitab ini cukup berbeda dengan lainnya. Daftar isi kitab tafsir ini terdiri dari tiga macam daftar isi yakni; daftar isi muṣhaf yaitu daftar isi yang berisi atas dasar kumpulan ayat saja sesuai surat yang terdapat dalam jilid kitab tersebut misalnya surah al-Fātihah terdapat pada halaman muṣhaf -muṣhaf dan halaman kitab 33. Kedua, daftar isi tafsir yaitu daftar isi yang berisi penafsiran atas dasar surat dalam jilid kitab tersebut misalnya penafsiran surat al-Fatihah terdapat pada halaman 35-37. Ketiga, daftar isi al-Mauḍ̄' 'àt yaitu daftar isi yang berisi atas dasar nama surah al-Qur'an yang terdapat dalam jilid kitab tersebut, misalnya surah al-Fatihah terdapat pada halaman 31-38.

Termasuk hal yang harus diketahui adalah dalam daftar isi muṣhaf terdapat dua macam halaman yakni halaman muṣhaf yaitu halaman yang diurutkan berdasar urutan kumpulan ayat sesuai muṣhaf. Halaman muṣhaf ini terletak di bawah bagian tengah. Misalkan surah al-Fatihah terdapat dalam halaman muṣhaf 2, kemudian surah al-Baqarah terdapat dalam halaman muṣhaf 3-42, dan halaman kitab yaitu halaman yang diurutkan berdasar urutan dari awal pembahasan sampai akhir baik berupa kumpulan ayat maupun penafsiran, halaman kitab terletak di sebelah atas pojok kanan atau kiri.

\section{Tafsir Muqātil bin Sulaymān sebagai "Kitab Tafsir sempurna Paling Awal"}

Perlu dibedakan terlebih dahulu antara mufassir paling awal, dan orang yang pertama kali mengkodifikasi tafsir. Mufassir paling awal adalah Rasulullah kemudian para Sahabat disusul Tabi'in. Adapun orang yang pertama kali membukukan tafsir terdapat perbedaan dikalangan ulama'. Ahmad Amīn berpendapat orang yang pertamakali membukukan tafsir adalah al-Farrā' (w. 207 H). Sedangkan Maḥmūd Shaḥātah menyatakan orang yang pertama kali mengkodifikasi tafsir adalah Muqātil bin Sulaymān. ${ }^{48}$

\footnotetext{
${ }^{48}$ Sulaymān, Tafsīr Muqātil bin Sulaymān, vol. 5, hlm. 64.
} 
Melacak Sumber dan Keotentikan Penafsiran Muqātil bin Sulaymān Ahmad Jauhari Umam

Doi: doi.org/10.47454/itqan.v5i1.710

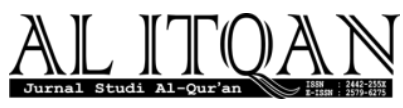

Hal yang membedakan tafsir Muqātil dengan tafsir lainnya yang sezaman dengannya adalah bahwa teks lengkap tafsirnya adalah sebagaimana ditulis olehnya sendiri secara sempurna. Lain halnya dengan Tafsir Mujāhid ${ }^{49}$ dan Tafsir Sufyān al-Thaurī, ${ }^{50}$ keduanya diduga hanya merupakan kumpulan kutipan dari sumber-sumber yang lebih belakang yang disusun dengan cara berlainan menjadi naskah dengan nama-nama mereka. ${ }^{51}$

Selain dua tafsir di atas, yang diklaim sebagai tafsir paling awal adalah Tafsir karya Ibn Abbās berjudul Tanwīr al-Miqbās min Tafsir Ibn Abbās. Namun, Kitab tersebut bukanlah kitab yang ditulis sendiri oleh Ibn Abbās namun kitab yang berisi riwayat-riwayat yang dinisbatkan kepada Ibn Abbās yang dikumpulkan oleh Muhammad bin Ya'qūb alFairūzābadīi ${ }^{52}$ Ada juga yang berpendapat bahwa Tafsir Ma'āni al-Qur'an karya Abū Zakariyā Yahyā bin Ziyād al-Farrā' adalah kitab tafsir pertama. ${ }^{53}$ Padahal biografi al-Farrā' sendiri menunjukkan ia lahir tahun $144 \mathrm{H}$ dan wafat 207 atau $208 \mathrm{H}$ yang jauh lebih belakang dibandingkan dengan Muqātilyang wafat tahun $150 \mathrm{H}$. Kebanyakan umat muslim mengatakan bahwa al-Ṭabarī (w. $310 \mathrm{H}$ ) adalah yang paling awal dengan karyanya yang paling masyhur, Jāmi’ al-Bayān fì Ta’wōl al-Qur'an. Bahkan al-Ṭabarī dijuluki sebagai Abū al-Tafsir atau bapak tafsir.

Jika dilihat dari deskripsi sebelumnya dapat diketahui bahwa kitab-kitab tafsir sebelum Muqātilbukanlah sebuah karangan yang ditulis sendiri akan tetapi riwayat yang dinisbatkan kepada mufassir tertentu, atau tidak lengkap penafsirannya secara sempurna 30 Juz atau dilihat dari biografinya muncul setelah Tafsir Muqātil bin Sulaymān. Sedangkan tafsir yang disebut-sebut paling awal seperti karya al-Farrā' dan al-Ṭabarī muncul setelah

\footnotetext{
${ }^{49}$ Mujahid lahir pada tahun $21 \mathrm{H}$ dan wafat tahun $104 \mathrm{H}$. Ada yang mengatakan Mujahid menulis kitab tafsirnya yang bersumber dari Ibn Abbas, kemudian dinukil oleh muridnya al-Qāsim bin Ab̄̄ Bazzah, kitabnya tersebut memang tidak menafsirkan keseluruhan ayat-ayat dalam al-Qur'an. Lihat Muhammad Fithri Umam, "Telaah Kritis terhadap Periodesasi Kodifikasi Muhammad Husyn al-Dhahabi dalam al-Tafsir wa al-Mufassirun", dalam Jurnal Al-Itqān vol. 2, no. 2, 2016, hlm. 11 (https://doi.org/10.47454/itqan.v1i1.12).

${ }^{50}$ Sufyān al-Thaurī lahir tahun $97 \mathrm{H}$ dan wafat tahun $161 \mathrm{H}$. Kitab tafsirnya ini berasal dari periwayatan Abū Khudhayfah Mūsa bin Mas'ūd al-Nahdī, dan tidak seluruh ayat dalam al-Qur'an ditafsirkan hanya lima puluh surah saja yaitu dari surah al-Baqarah samapi al-Ṭūr dengan tidak menafsirkan surah al-Dukhān dan al-Qitāl. Ibid., hlm. 17.

${ }^{51}$ Versteegh, "Tafsir Quran Paling Awal: Tafsir Muqātil”, hlm. 211.

${ }^{52}$ Muhammad bin Ya'qūb al-Fairūzābadī, Tanwīr al-Miqbās min Tafsir Ibn Abbās, hlm. 2. Al-Shāfi'̄̄ mengatakan riwayat-riwayat tentang tafsir yang dapat dipastikan dari Ibn Abbās hanya sekitar seratus hadith. Lihat Sulaymān, Tafsīr Muqātil bin Sulaymān, vol. 5, hlm. 61.

${ }^{53}$ Tafsir ini tidak keseluruhan menafsirkan ayat al-Qur'an, hal ini dapat terlihat misalnya pada surah al-A'rāf setelah menafsirkan ayat 155 kemudian langsung menafsirkan ayat 160, sehingga ada 5 ayat yang tidak ditafsirkan, hal ini juga terdapat pada tempat-tempat yang lain. Lihat Sulaymān, Tafsīr Muqātil bin Sulaymān, vol. 5, hlm. 65 .
} 
Muqātil dilihat dari biografinya. Sehingga tidak diragukan lagi bahwa Tafsir Muqātil bin Sulaymān merupakan tafsir lengkap 30 Juz paling awal yang sampai kepada kita. ${ }^{54}$

\section{Kelebihan dan Kekurangan Tafsir Muqātil bin Sulaymān}

Sebagai sebuah bentuk produk penafsiran, kitab ini memiliki beberapa kelebihan diantaranya:

a. Memperhatikan munāsabah ayat (konteks keterkaitan antar ayat). Dapat dijumpai bahwa ia sering mengaitkan ayat al-Qur'an dilihat dari tema maupun ayat yang berdekatan dengan menggunakan kata sambung;

b. Menyebutkan perbedaan qirā'àt. Ketika mengarang kitabnya, qirā' $\bar{a} t$ sab'ah masih belum masyhur. ${ }^{55}$ Sehingga qirā' $a ̂ t$-nya masih bersumber dari Sahabat;

c. Memperhatikan siyāq al-kalām. Maka tidak heran jika ia banyak mengartikan beberapa lafal yang sama tapi dengan arti yang berbeda-beda;

d. Penjelasan mengenai al-mubhamāt seperti nama orang atau tempat yang masih samar.

Namun begitu, kitab ini juga tidak lepas dari kekurangan, antara lain: pertama, banyak memotong bahkan tanpa disertai jalur sanad. Kedua, terdapat banyak kisah isrā'iliyyāt tanpa sanad dan tanpa komentar. Ketiga, tidak menjelaskan makna secara linguistik (sisi nahwushorof). Keempat, tidak konsisten dalam menafsirkan ayat-ayat tajsìm.

\section{Penyaliban dan diangkatnya Nabi Isa ke langit dalam Tafsir Muqātil bin Sulaymān}

Topik tentang kisah penyaliban dan diangkatnya Nabi Isa ke langit dalam al-Qur'an terdapat pada Q.S. Āli 'Imrān: 55 dan Q.S. al-Nisa': 157-158. Karena dalam Tafsir Muqātil bin Sulaymān sangat menekankan konteks munasabah suatu ayat, sehingga perlu memaparkan juga penafsiran ayat sebelumnya atau setelahnya sehingga cerita akan terlihat berkesinambungan. Maka, Penelitian ini menjadikan Q.S. Āli 'Imrān: 54-55 dan Q.S. alNisa’: 157-158 sebagai fokus penelitian.

\section{Penyaliban dan diangkatnya Nabi Isa ke langit pada Q.S. Āli ‘Imrān: 54-55}

\footnotetext{
${ }^{54}$ Ibid., vol. 5, hlm. 61.

${ }^{55}$ Peletak dasar ilmu Qira'at menurut satu pendapat adalah Abū 'Amr Hafṣ bin Sulayman al-Dūrī, dan yang pertamakali membukukan adalah Abū Ubā̄d al-Qāsim bin Salām (w. 224 H). lihat Muhammad Abbās al-Bāz, Mabāḥith fì 'Ilm Qirā'āt ma'a Bayāni Ușūli Riwāyah Hasfṣ (Kairo: Dar al-Kalimah, 2004), hlm. 39.
} 


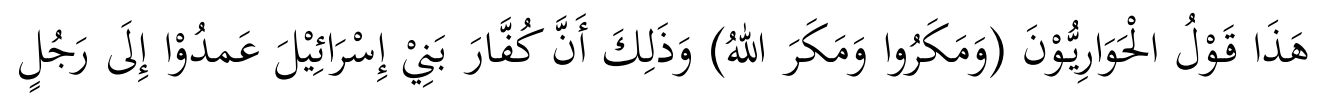

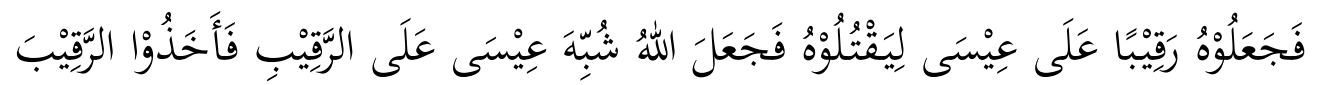

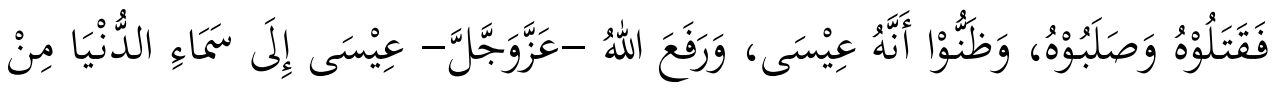

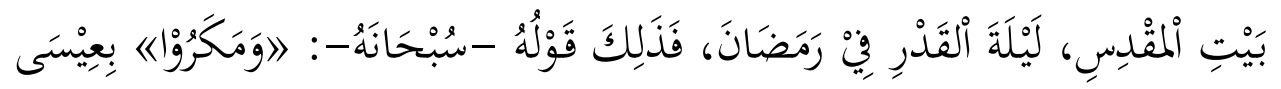

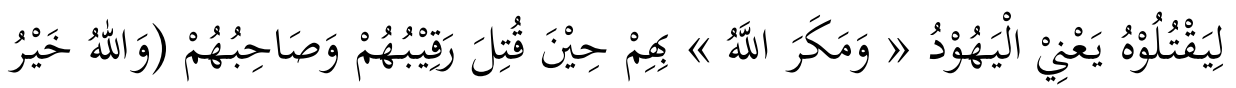

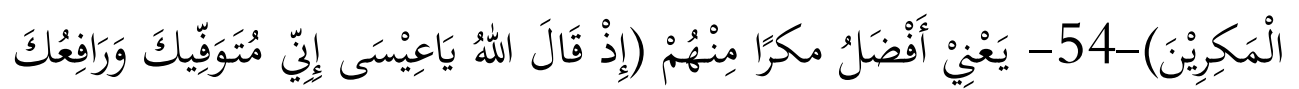

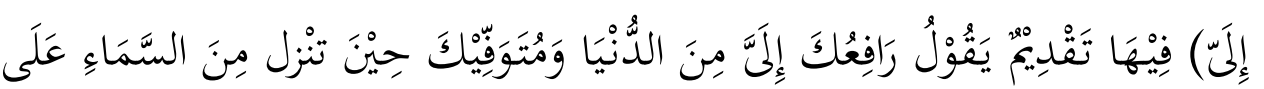

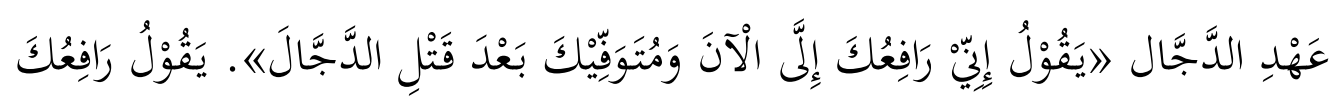

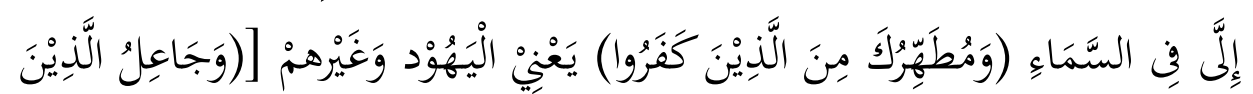

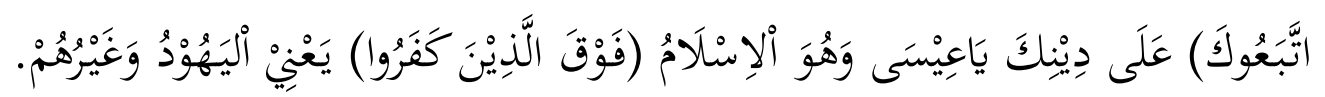

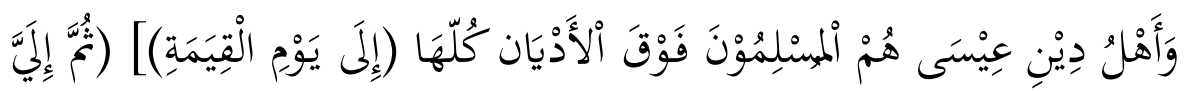

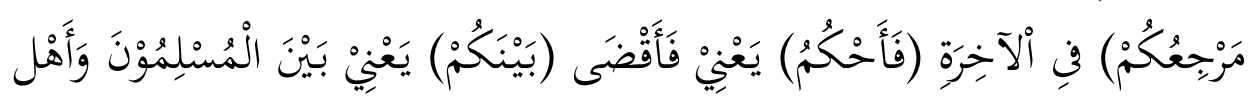

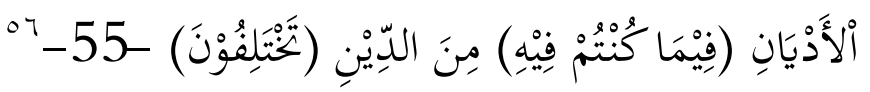

Ini merupakan ungkapan al-Hawäriyyīn (Orang-orang kafir itu membuat tipu daya, dan Allah membalas tipu daya mereka itu), karena sesungguhnya saat itu kafir Bani Isra'il mengiginkan seorang laki-laki yakni 'İsā untuk dijadikan sebagai budak dan kemudian dibunuh. Namun, Allah menjadikan budak yang mirip dengan İsā tersebut sehingga budak ini ditangkap oleh kafir Bani Isra'il untuk dibunuh dan disalib, mereka menduga yang mereka bunuh adalah İsā. Padahal Allah mengangkat İsā dari bumi Bait al-Maqdis pada malam Lailatu al-Qadr di bulan Ramadhan. Dari peristiwa itulah kemudian Allah berfirman (mereka orang Yahudi membuat tipu daya) pada İsā agar bisa dibunuh. (dan Allah membalas tipu daya mereka itu) saat mereka membunuh budak tersebut (Dan Allah sebaik-baik memperdaya) yakni sebaik-baik pembalas tipu daya. 54- ((Ingatlah), ketika Allah berfirman: "Hai Isa, sesungguhnya Aku akan menyampaikan kamu kepada akhir ajalmu dan mengangkat kamu kepada-Ku) dalam ayat tersebut ada hal yang mestinya didahulukan namun diakhirkan, yaitu ucapan mengangkatmu dari langit dunia kemudian mewafatkanmu ketika kamu turun dari langit pada masa dajjal. Seharusnya ayat tersebut dengan redaksi "Aku mengangkatmu saat ini dan mewafatkanmu setelah terbunuhnya dajjal" yakni mengangkatmu ke langit. (serta membersihkan kamu dari orangorang yang kafir) yakni orang-orang Yahudi dan lainnya. (dan menjadikan orang-orang yang mengikuti kamu) atas agamamu wahai Isa yakni agama Islam. (di atas orang-orang yang kafir) yakni orang Yahudi dan lainnya,

\footnotetext{
${ }^{56}$ Sulaymān. Tafsīr Muqātil bin Sulaymān, vol. 1, hlm. 278 - 279.
} 
pemeluk agama Isa mereka adalah orang-orang muslim yang mengungguli semua agama (hingga hari kiamat). (Kemudian hanya kepada-Kulah engkau kembali) ke akhirat (lalu Aku menghukumi) yakni memutuskan (di antara kalian) yakni antara kaum muslim dan pemeluk agama-agama (tentang hal-hal yang di dalamnya) dari agama (kalian perselisihkan) -55-.

Pada surah Āli 'Imrān ayat 54, Muqātil menjelaskan bahwa kaum kafir Bani Isrā̄il menginginkan 'Īsā karena mereka berniat ingin menjadikannya budak dan akan membunuhnya. Namun yang terjadi justru orang lain diserupakan oleh Allah mirip dengan 'Īsā sehingga kaum kafir membunuh dan menyalib orang tersebut. Sedangkan 'Īsā diangkat oleh Allah ke langit dunia dari Bait al-Maqdis, pada malam Lailatu al-Qadr bulan Ramadhan. Terlihat pada ayat ini bahwa Muqātil tidak menyebutkan nama siapa orang yang diserupakan dengan 'Īsā, hanya menjelaskan bahwa yang disalib bukanlah 'Īsā tapi orang lain. Penafsiran ayat ini juga tidak terlihat adanya kutipan-kutipan riwayat. Akan tetapi ketika kita melacak pada literatur lain ditemukan beberapa riwayat yang semakna dengan apa yang dijelaskan Muqātil. Seperti yang disebutkan al-Ṭabarī dalam Tafsir Jāmi' al-Bayān fì Ta'wīl al-Qur'an meriwayatkan bahwa 'Īsā diangkat ke langit dan yang disalib bukanlah 'Īsā, riwayat tersebut sebagai berikut:

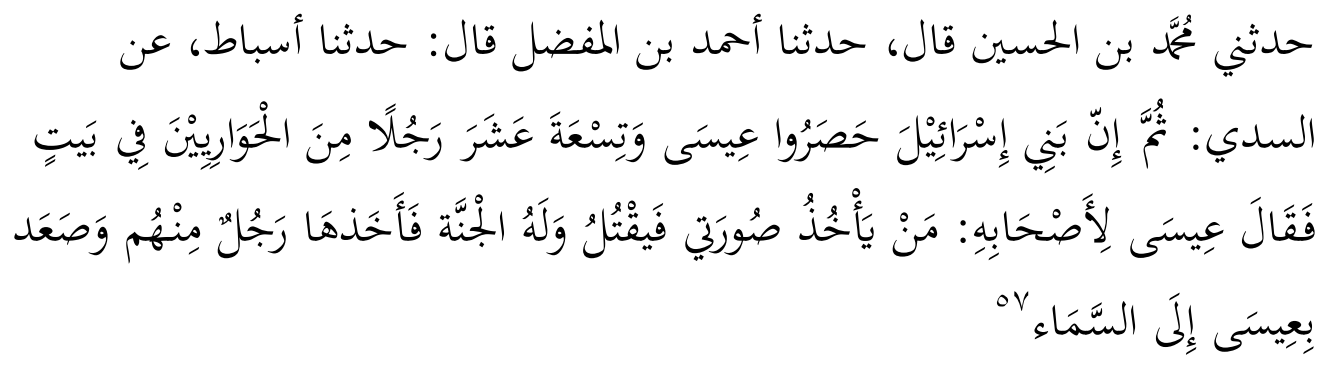

Mengabarkan kepadaku Muhammad bin al-Husaīn, ia berkata mengabarkan kepada kami Ahmad bin al-Mufạ̣̣̣al, ia berkata mengabarkan kepada kami Asbāṭ dari al-Sudy, "Sesungguhnya Bani Isrā̄il mengepung Īsa dan sembilan belas orang dari Hawāriyyīn di Rumah", kemudian Îsa berkata kepada para sahabatnya, "Barangsiapa yang menyerupaiku maka ia akan dibunuh dan baginya surga, maka dari Ḥawāriyyīn ada seseorang yang menginginkan hal itu, kemudian İsa diangkat ke langit”.

Riwayat ini mendukung penjelasan Muqātil dari sisi bahwa bukanlah 'Īsā yang dibunuh dan disalib akan tetapi ada seseorang yang diserupakan dengannya, dan 'Īsā diangkat ke langit oleh Allah. Al-Suyūṭi juga mengutip riwayat ini dalam kitab Tafsirnya, al-Dur al-

\footnotetext{
${ }^{57}$ Muhammad bin Jarīr al-Ṭabarī, Jāmi' al-Bayān fĩ Ta'wīl al-Qur'an, vol. 6 (t.tp: Mu'assasah al-Risalah, 2000), hlm. 454.
} 
Melacak Sumber dan Keotentikan Penafsiran Muqātil bin Sulaymān

Ahmad Jauhari Umam

Doi: doi.org/10.47454/itqan.v5i1.710

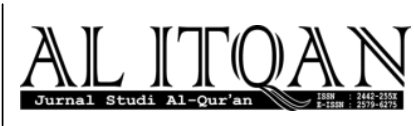

Manthūr, 2 : 224. Riwayat ini sanadnya Muttasil akan tetapi hanya sampai pada al-Sudīy yang tergolong dalam generasi Tabi'in, jadi termasuk dalam hadis Maqtū'.

Riwayat lain sebagai pendukung bahwa 'Īsā akan turun dari langit pada zaman Dajjal adalah riwayat Abī Ḥātim dalam tafsirnya, riwayatnya sebagai berikut:

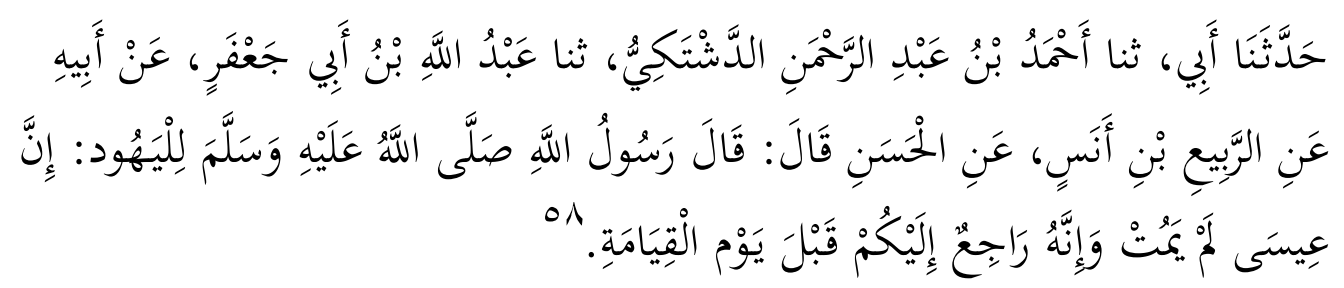

Telah meriwayatkan kepada kami ayahku, telah meriwayatkan kepada kami Ahmad bin Abd al-Rahman al-Dashtakī telah meriwayatkan kepada kami Abdullah bin Abī Ja'far dari ayahnya dari al-Rabi' bin Anas dari al-Hasan. Ia berkata, Rasulullah berkata kepada kaum Yahudi, "Sesungguhnya Isa tidak mati dan sesungguhnya ia akan kembali kepada kalian (Yahudi) sebelum hari kiamat".

Al-Hasan yang dimaksud adalah Hasan Bașrī yang merupakan seorang Tabi’in (w. $110 \mathrm{H}$ ), sehingga riwayat ini tergolong dalam hadith Mursal (terputus pada jalur Sahabat). Maka riwayat ini tidak bisa diterima karena syarat hadith Mursal bisa dijadikan hujjah tidak terpenuhi yaitu Tidak ditemukan riwayat lain yang mendukung riwayat ini, tidak didukung oleh pakar hadith terpercaya lainnya, Tabi' in tersebut tidak dikatakan thiqqah oleh orang yang meriwayatkannya. Muhammad Ahmad Isma'il mengomentari riwayat ini dalam Tafsir alQur'an al-Karim dengan Hadith Mursal daĭf .

Wahbah al-Zuhaylī dalam Tafsīr Munīr juga mengutip redaksi yang sama dengan riwayat diatas yakni:
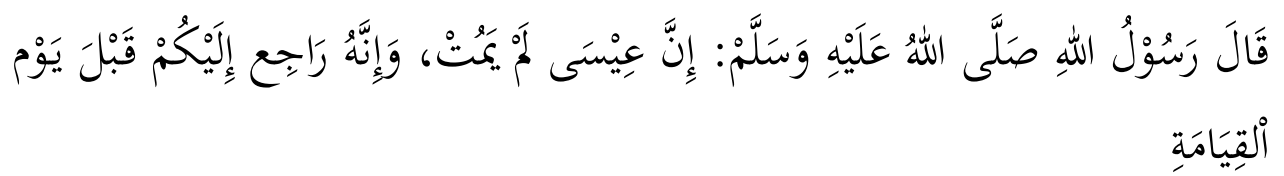

Namun al-Zuhaylī tidak menyertakan riwayat lengkapnya dan tanpa disertai dengan sanad. Menurutnya keterangan tersebut merupakan hadith Șahī h. ${ }^{59}$

Al-Suyūṭ̂̀ meriwayatkan sebagai berikut:

\footnotetext{
${ }^{58}$ Abū Muhammad Abd al-Rahman al-Rāzī Ibn Abī Hāātim, Tafsīr al-Qur'an al- 'Aẓīm li Ibn Abī Hātim, vol. 4 (Saudi Arabia: Maktabah Nizar Mustafa al-Baz, 1999), hlm. 1110.

${ }^{59}$ Wahbah bin Mușṭafā al-Zuhaylī, al-Tafsīr Munīr, vol. 3 (Damaskus: Dar al-Fikr, 1997), hlm. 241.
} 


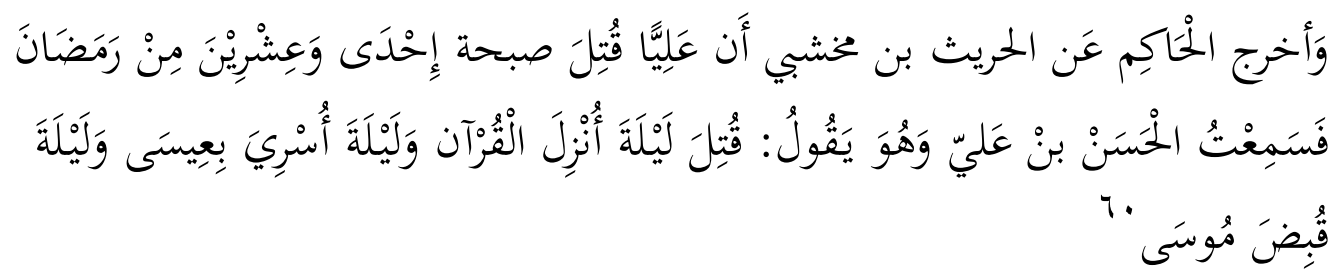

Telah meriwayatkan al-Hākim dari al-Huraīth bin Makhshy, "Sesungguhnya Ali dibunuh pagi hari pada tanggal dua puluh satu bulan Ramadhan". Kemudian saya mendengar al-Hasan bin Ali ia berkata, "Ia dibunuh pada malam diturunkannya al-Qur'an, dan pada malam dimana İsa diperjalankan dan pada malam dimana Musa wafat".

Riwayat ini diriwayatkan dari Abū al-Walīd al-Haitam bin Khalaf al-Dūry, dari Sawwār bin Abdullah al-'Anbary dari al-Mu’tamir dari ayahnya (Sulayman bin Țarkhān) dari al-Ḥuraīth bin Makhshī. Setelah ditakhrij Sanadnya Sahịḥ, dan termasuk kategori hadith Mauqūf. ${ }^{61}$

Riwayat ini menerangkan secara tidak langsung bahwa 'Īsā diangkat pada bulan Ramadhan, secara tidak langsung riwayat ini mendukung penafsiran Muqatil yang menyatakan 'Īsā diangkat pada bulan Ramadhan. ${ }^{62}$ Namun tidak ada riwayat yang mendukung Muqātil bahwa 'Īsā diangkat ke langit pada malam Laitu al-Qadr.

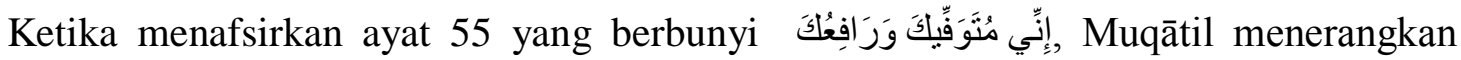
bahwa 'Īsā diangkat dari dunia kemudian akan wafat ketika turun dari langit setelah membunuh Dajjal. Terlihat bahwa Muqātil saat menafsirkan ayat tersebut menerangkan bahwa terdapat rangkaian kalimat yang didahulukan dan ada pula kalimat yang diakhirkan. Ibn Abī Ḥātim mengutip riwayat yang mendukung keterangan ini, riwayatnya sebagai berikut:

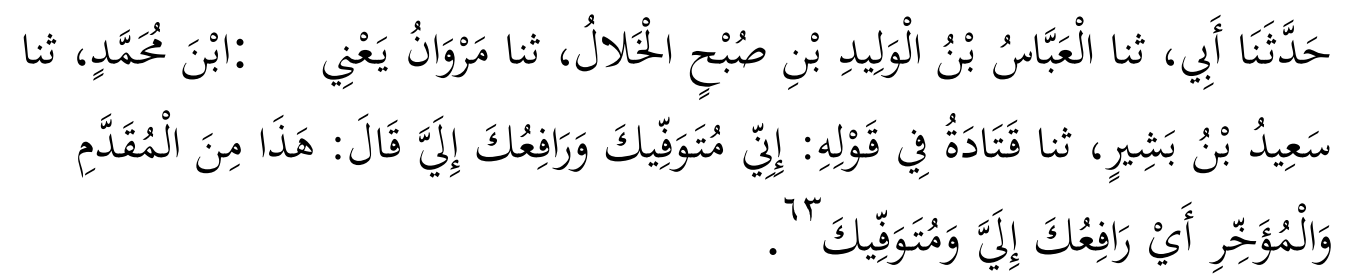

Telah mengabarkan kepada kami ayahku, mengabarkan kepada kami al-'Abbās bin al-Walīd bin Subḥ, mengabarkan kepada kami Marwān yakni Ibn Muhammad, mengabarkan kepada kami Sa'īd bin Bashīr , mengabarkan

\footnotetext{
${ }^{60}$ Jalāl al-Dīn Abdurrahman al-Suyūțī, al-Dur al-Manthūr, vol. 2 (Beirut: Dar al-Fikr, t.th), hlm. 226.

${ }^{61}$ Abū Abdullah al-Ḥākim Muhammad al-Naisābūrī, al-Mustadrak 'alā al-Ṣaḥịhain, vol. 3 (Beirut: Mustafa Abd al-Qadir 'Ata, 1990), hlm. 153.

${ }^{62}$ Muqatil sendiri menjelaskan 'Īsā diangkat pada Lailatu al-Qadr, dikuatkan juga ketika menafsirkan surah alQadr Muqatil menerangkan bahwa al-Qur'an diturunkan pada malam Lailatu al-Qadr yakni pada bulan Ramadhan. Lihat Sulaymān. Tafsīr Muqātil bin Sulaymān, vol.4, hlm. 771.

${ }^{63}$ Abī Hātim, Tafsìr al-Qur'an al- 'Aẓ̂̀m li Ibn Abì Hātìm, vol.4, hlm. 1110.
} 
Melacak Sumber dan Keotentikan Penafsiran Muqātil bin Sulaymān Ahmad Jauhari Umam

Doi: doi.org/10.47454/itqan.v5i1.710

kepada kami Qatādah mengenai firman Allah "Sesungguhnya Aku telah mewafatkanmu dan mengangkatmu kepadaku" ia berkata, ini ungkapan yang didahulukan dan diakhirkan maksudnya mengangkatmu kepadaku dan mewafatkanmu.

Riwayat ini disandarkan pada Qatādah yang merupakan seorang Sahabat sehingga termasuk pada hadith Mauqūf, dan riwayatnya Hasan karena ada rawi yang tidak sempurna kethiqqahannya.

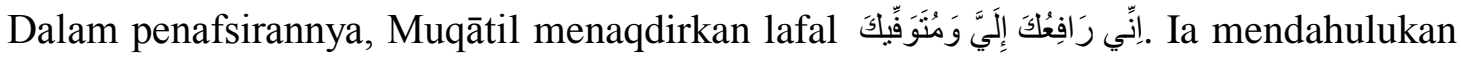

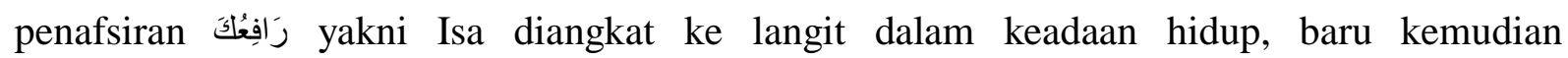

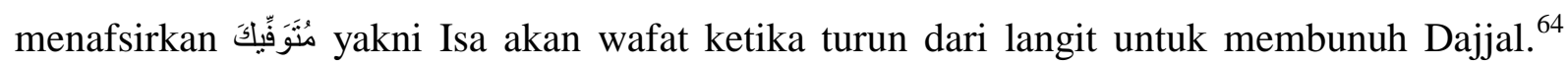
Sehingga asumsinya adalah Allah mengangkat 'Īsā, menyucikannya dari orang-orang kafir, kemudian mewafatkannya setelah Allah menurunkannya diakhir zaman. ${ }^{65}$

Al-Ṭabarī menerangkan sebagaimana yang dijelaskan Muqātil bahwa maksud dari ‘'̄sā disucikan dari orang kafir adalah dari kaum Yahudi. Riwayatnya sebagai berikut:

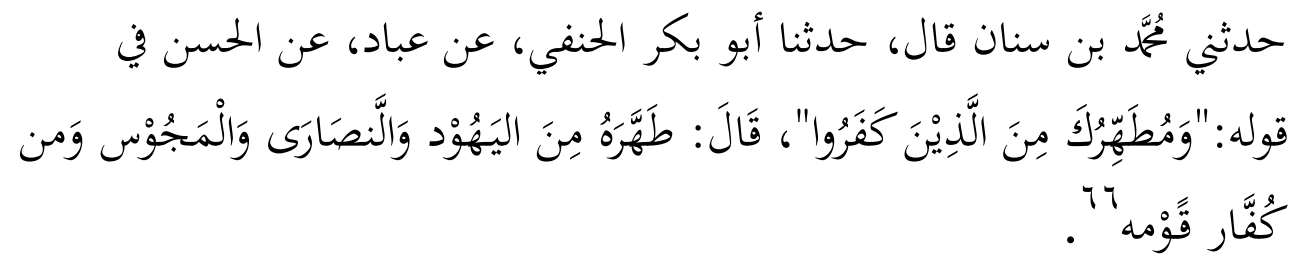

Telah mengabarkan kepadaku Muhammad bin Sanān, ia berkata telah mengabarkan kepadaku Abū Bakar al-Hanafĩ dari Ubbād dari al-Hasan tentang firman Allah "Dan kamu ('Īsā) disucikan dari orang-orang kafir", ia berkata 'Īsā disucikan dari (tuduhan) kaum Yahudi, Nasrani, Majusi dan dari kaumnya yang kafir.

Riwayat ini $D a$ 'îf karena ada rawi riwayat tersebut yakni Muhammad bin Sinān dan Ubbād dinilai tidak thiqqah hingga seorang mudallis. Sehingga riwayat ini tidak dapat dijadikan sebagai hujjah karena tidak berhubungan dengan fadail a'māl dan tidak ada riwayat lain yang mendukungnya.

\footnotetext{
${ }^{64}$ Penafsiran seperti ini juga terdapat dalam al-Ṭabarī Jāmi' al-Bayān fì Ta'wīl al-Qur'an, $6: 458$. pada Ismā' $\mathbf{1} l$ bin Umar bin Kathīr, Tafsir al-Qur'an al- 'Ażīm, vol. 2 (t.tp: Dar Ṭayyibah li Nashr wa al-Tauzi', 1999), hlm. 46. Dan Pada al-Suyūṭî, al-Dur al-Manthūr, vol. 2, hlm. 225.

${ }^{65}$ Ali Muhammad Al-Șallabi, Isa bin Maryam Kelahiran, Kerasulan, Kisah Penyaliban hingga Turunnya Kembali di Akhir Zaman (Jakarta: Ummul Qura, 2020), hlm. 539.

${ }^{66} \mathrm{Al}-\mathrm{T}$ abarī, Jāmi' al-Bayān fì Ta' wìl al-Qur'an, vol. 6, hlm. 461- 462.
} 


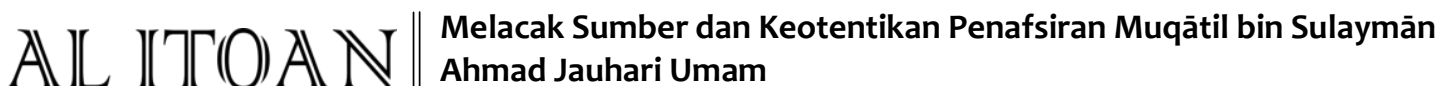 \\ Doi: doi.org/10.47454/itqan.v5i1. 710}

\section{Penyaliban dan diangkatnya Nabi Isa ke langit pada Q.S. al-Nisā': 157-158}

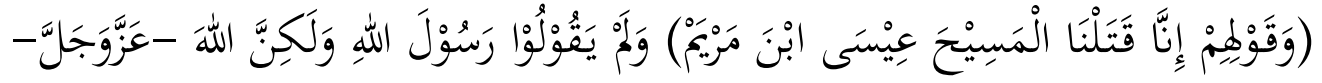

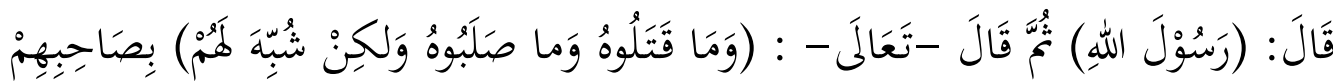

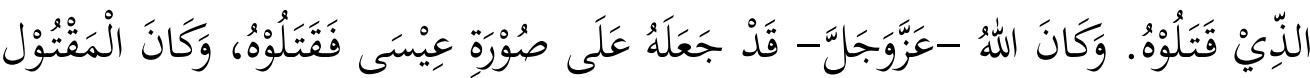

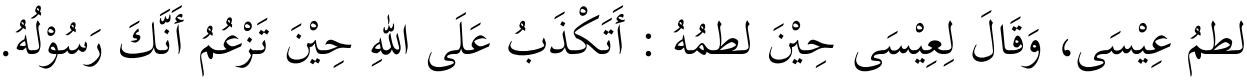

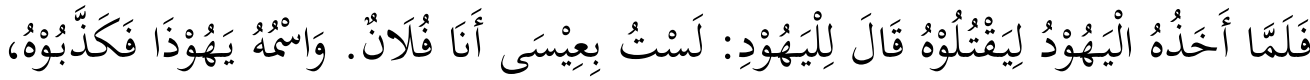

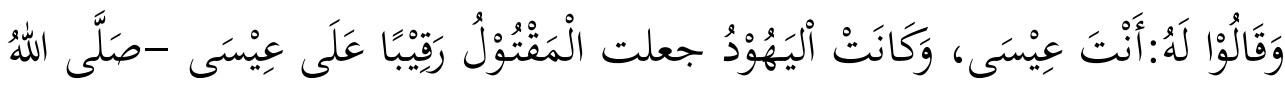

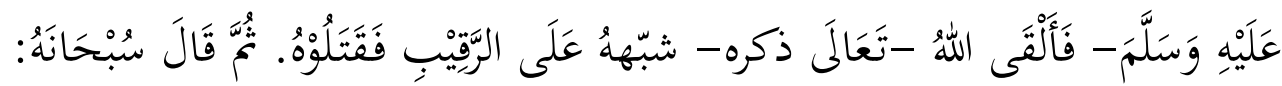

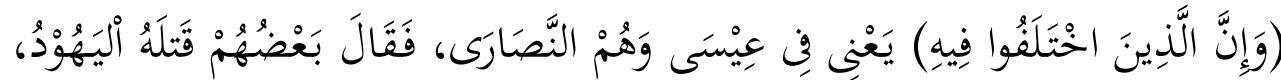

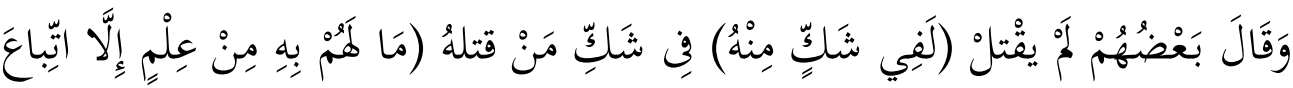

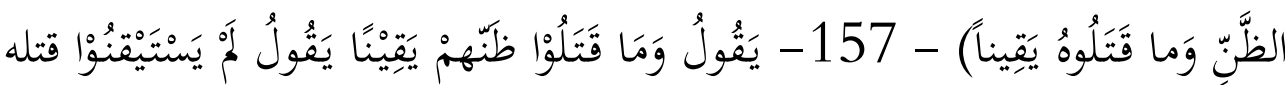

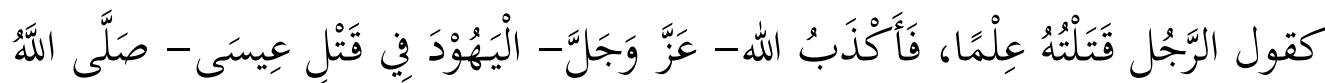

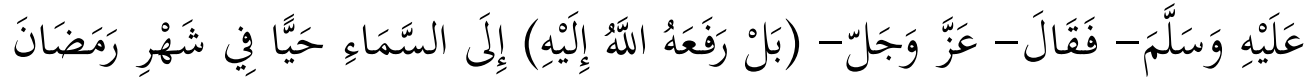

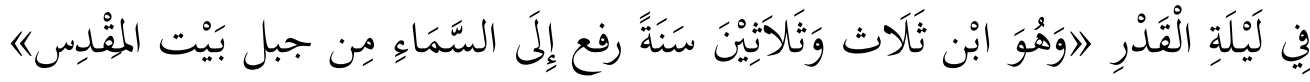

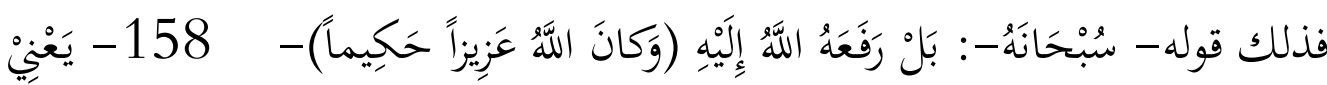

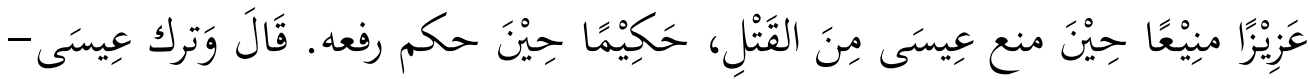

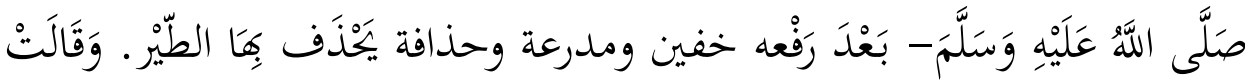

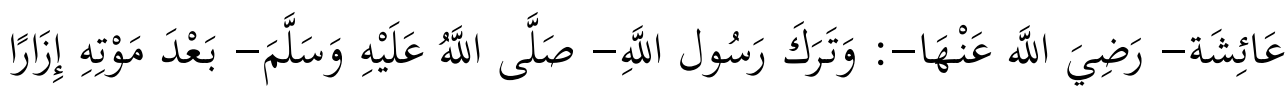

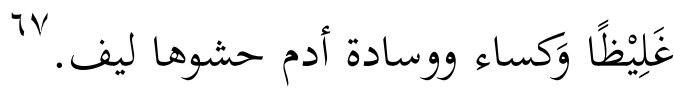

(Dan karena ucapan mereka: "Sesungguhnya kami telah membunuh al-Masih, 'Īsā putra Maryam) mereka tidak mengatakan utusan Allah, tetapi Allah berfirman (Ia adalah Utusan Allah). Kemudian Allah berfirman (padahal mereka tidak membunuhnya dan tidak (pula) menyalibnya, tetapi (yang mereka bunuh ialah) orang yang diserupakan dengan 'I sā bagi mereka) dengan teman mereka sendiri yang mereka bunuh. Allah menjadikan teman mereka mirip dengan 'Īsā yang kemudian mereka bunuh. Orang yang mereka bunuh adalah orang yang pernah menampar 'İsā. Saat menampar 'Īsā ia berkata "Apakah kau berbohong kepada Allah saat kau mengira bahwa kau adalah

\footnotetext{
${ }^{67}$ Sulaymān. Tafsīr Muqātil bin Sulaymān, vol. 1, hlm. 420.
} 
Melacak Sumber dan Keotentikan Penafsiran Muqātil bin Sulaymān Ahmad Jauhari Umam Doi: doi.org/10.47454/itqan.v5i1.710

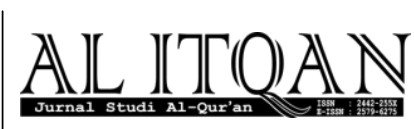

utusannya”. Saat akan dibunuh oleh Yahudi ia berkata,’Aku bukan 'Īsā, aku adalah Fulan". Namanya adalah Yahūz̄ā, namun ia dianggap berbohong. Dan dijawab oleh mereka, "Kau adalah 'İsā". Dimana sebelumya orang Yahudi menjadikan orang yang dibunuh sebagai budak 'İsā -Sallā Allahu 'Alaihi wa Sallam-, kemudian Allah menyerupakan budak tersebut dengan 'Īsā dan dibunuh oleh mereka kaum Yahudi. Kemudian Allah berfirman (Sesungguhnya orang-orang yang berselisih paham tentang perihal) yakni tentang pembunuhan 'İsā mereka adalah kaum Nasrani. Sebagian dari kaum Nasrani mengatakan bahwa kaum Yahudi lah yang membunuh 'Īsā dan sebagian lain mengatakan tidak dibunuh. (benar-benar dalam keragu-raguan tentang yang dibunuh itu) ragu akan pembunuhan Isa. (Mereka tidak mempunyai keyakinan tentang siapa yang dibunuh itu, kecuali mengikuti persangkaan belaka, mereka tidak (pula) yakin bahwa yang mereka bunuh itu adalah 'Isā) -157- bahwa apa yang mereka bunuh itu hanya sebuah persangkaan mereka yang mereka yakini, tidak yakin telah membunuhnya seperti ucapan seseorang, "Saya membunuhnya". Maka Allah menerangkan kebohongan orang Yahudi dalam pembunuhan 'Īsā - Sallā Allahu 'Alaihi wa Sallam -. Kemudian Allah berfirman (Tetapi, Allah telah mengangkat Isa kepada-Nya) kelangit dalam keadaan hidup saat malam lailatu al-qadr pada bulan Ramadlan ((dan dia berumur tiga puluh tiga tahun saat diangkat ke langit dari gunung Bait al-Maqdis)) demikianlah firman Allah "Tetapi, Allah telah mengangkat "Īsā kepada-Nya" (Dan adalah Allah Maha Perkasa lagi Maha Bijaksana) -158- yakni Maha Perkasa, Maha Melindungi ketika mencegah 'Īsā dari terjadinya pembunuhan, Maha Bijaksana ketika memutuskan mengangkatnya. 'Īsā setelah diangkat ke langit, ia meninggalkan sandal, jubah, dan bekas duduk yang kemudian semuanya dihilangkan oleh burung. 'Aisyah radiya Allahu 'anha berkata, "Rasulullah Șallā Allahu 'Alaihi wa Sallam setelah wafat meninggalkan selimut tebal, pakaian, bantal berwarna sawo matang yang bahannya dari sabut"

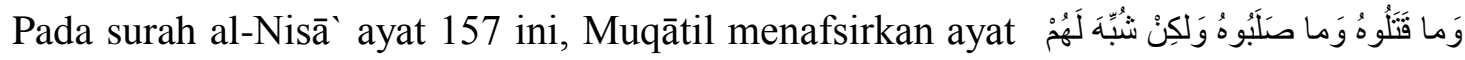
bahwa orang yang dibunuh dan disalib bukanlah Nabi 'Īsā akan tetapi orang yang diserupakan dengan 'Īsā. Muqātil menerangkan orang yang diserupakan dengan 'Īsā adalah teman kaum Yahudi sendiri namanya Yahūẓā. Yahūẓā juga pernah menampar 'Īsā karena mengingkari ‘'̄sā sebagai utusan Allah. Menurut Ibn 'Āshūr, Yahūẓā merupakan salah satu dari pengikut alMasīh yang sesat dan munafiq. Dialah yang memfitnah 'İsā sehingga Allah memberikan pelajaran baginya dengan diserupakan dengan 'Īsā dan akhirnya ia yang disalib.

Penafsiran yang mengatakan bahwa orang yang diserupakan dengan 'İsā bernma Yahūẓā, menurut Muhammad Ahmad Ismā'̄ill masyhur di kalangan Ahli Kitab, ${ }^{68}$ Penafsiran yang sama ini juga terdapat dalam Tafsir al-Tahrī̀ wa al-Tanwīr. Bahkan Ibn 'Āshūr al-

\footnotetext{
${ }^{68}$ Muhammad Ahmad Ismā’̄̄l, Tafsir al-Qur'an al-Karìm, (Durus Sautiyah Qam bi Tafri'iha Mauqi al-Shubkah al-Islamiyah dalam http://www.islamweb.net), vol. 7, hlm. 48.
} 
Tūnisī menjelaskan bahwa penafsiran tersebut merupakan dasar dari Injil Barnabas. ${ }^{69}$ Menurut salah satu keterangan, Barnabas adalah salah satu murid al-Hawāriyyīn. ${ }^{70}$ Hal yang sama juga diterangkan dalam Tafsir al-Manār bahwa dalam Injil Barnabas dijelaskan para tentara mengira bahwa Yudas Iskariot adalah al-Masīh karena ia telah diserupakan dengannya. ${ }^{71}$

Ketika kita merujuk pada Injil Barnabas memang dijelaskan bahwa yang diserupakan dengan 'Īsā adalah Yudas Iskariot (Yahūẓā al-Iskhiryūṭī), sedangkan 'Īsā diangkat ke langit oleh Allah. Hal ini terdapat pada beberapa pasal yang berbunyi:

Maka ketika Allah melihat bahaya yang menghampiri hamba-Nya, diperintahkanlah oleh-Nya para malaikat-Nya Jibril, Mikhail, Rufail dan Uril, utusan-utusanya itu untuk mengambilnya dari dunia ini. Dan tibalah para malaikat yang suci itu lalu diambilnyalah Yesus dari jenis yang menghadap ke sebelah selatan. Kemudian diangkatlah dia dan diletakkannya dilangit yang ketiga, ditengah kawanan malaikat yang memuji-muji Allah sepanjang masa. (Pasal 215 tentang "Tibanya para Malaikat Jibril, Mikhail, Rufail dan Uril" ayat 4-6). ${ }^{72}$

Lalu berubahlah Yudas itu dalam kata-kata dan wajahnya, sehingga ia menyerupai Yesus, dan kamipun menyangkanya Yesus. (Pasal 216 tentang "Yudas dan para murid" ayat 4

Dan ditengah-tengah ia mengatakan demikian itumasuklah tentara itu lalu meletakkan tangan mereka kepada Yudas, karena ia benar-benar menyerupai Yesus dalam segala hal. (Pasal 216 tentang "Yudas dan para murid" ayat 9) ${ }^{73}$

Maka diangkatlah Yudas oleh tentara dan diikatlah ia sambil mengejekejeknya. Karena ia mungkir sedang ia bertutur benar bahwa dia itu bukan Yesus (Pasal 217 tentang "Yudas dan tentara" ayat 1-2)

\footnotetext{
${ }^{69}$ Injil Barnabas adalah sebuah manuskrip di Italia yang ditulis pada abad ke-16 yang menggambarkan kehidupan Yesus. Barnabas sendiri adalah seorang tokoh diantara murid-murid Yesus. Injil ini masih diperdebatkan kredibilitasnya. Bahkan banyak literatur barat yang menyebut Injil Barnabas sebagai dokumen palsu. Injil ini memiliki pararel yang kuat dengan Islam, bukan hanya menyebut langsung nama Muhammad didalamnya, tetapi juga mencakup syahadat, sangat anti Paulus dan anti Trinitas, didalamnya dinyatakan bahwa Yesus digambarkan sebagai Nabi dan bukan anak Allah, dijelaskan juga Yesus selamat dari penyaliban karena ia diangkat hiduphidup ke surga, sementara Yudas Iskariot sang penghianat disalib sebagai gantinya. Secara garis besar dokumen ini seperti ingin menampilkan Yesus versi Qur'an dan diduga kuat dokumen ini ditulis supaya pembacanya berpindah agama menjadi Islam. Lihat: Norman Daniel, "Christian-Muslim Polemics" dalam Lindsay Jones (ed.), Encyclopedia of Religion (New York: Thmson-Gale, 2003), hlm. 7243.

${ }^{70}$ Muhammad al-Ṭāhir bin 'Āshūr al-Tūnisī, al-Tahrīr wa al-Tanwīr min Tafsīr al-Kitāb al-Majìd, vol. 6 (Tunisia: al-Dar al-Tunisiyah li Nashr, 1984), hlm. 21.

${ }^{71}$ Muhammad Rashid Riḍ̄a, Tafsìr al-Qur'an al-Karīm, vol. 6 (Mesir: Hai'ah al-Misriyah al-'Ammah li al-Kitab, 1990), hlm. 17.

${ }^{72}$ Injil Barnabas terj. Husin Abu Bakar Alhabsyi dan Abu Bakar Basymeleh (Surabaya: Mutiara Ilmu, 1996), hlm.331.

${ }^{73}$ Ibid., hlm. 332.

${ }^{74}$ Ibid., hlm. 333.
} 
Melacak Sumber dan Keotentikan Penafsiran Muqātil bin Sulaymān

Ahmad Jauhari Umam

Doi: doi.org/10.47454/itqan.v5i1.710

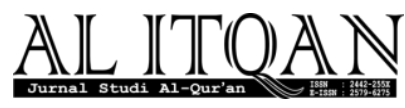

Setelah dilakukan pelacakan, penulis tidak menemukan riwayat yang menyatakan bahwa yang disalib adalah orang yang bernama Yahūẓā. Berarti dalam hal ini Muqātil mengambil sumber kisah Isrāīliyyāt dari ahli kitab tanpa adanya periwayatan dan termasuk kisah Isrāīliyyāt yang tidak bertentangan dengan al-Qur'an (Ali Imran 55 dan al-Nisa' 157) tapi didiamkan karena tidak dapat dipastikan kebenarannya; tidak dibenarkan dan juga tidak didustakan.

Pada ayat 158, Muqātil menafsirkan ayat بَلْ رَفَعَهُ اللَّْ إِلَيْهِ bahwa 'Īsā diangkat ke langit oleh Allah dalam keadaan hidup pada malam lailatu al-qadr bulan Ramadlan dan dia berumur tiga puluh tiga tahun saat diangkat ke langit dari gunung Bait al-Maqdis. Terdapat riwayat yang menyatakan 'Īsā diangkat dalam keadaan hidup, diriwayatkan oleh Mujāhid yang berbunyi:

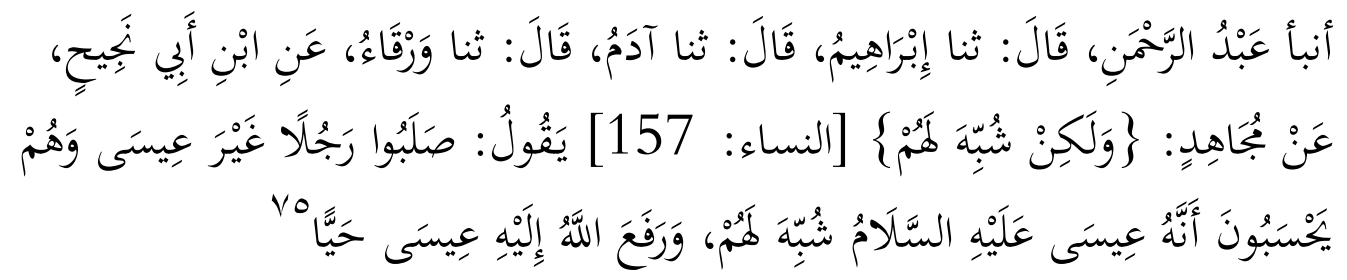

Telah memberitahukan Abdurrahman, ia berkata telah mengabarkan kepada kami Ibrahim, ia berkata telah mengabarkan kepada kami Ādam ia berkata telah mengabarkan kepada kami Warqā’ dari Ibn Abī Naj̄̄h dari Mujāhid: \{akan tetapi diserupakan dengan 'Īsā bagi mereka\}, ia mengatakan: mereka menyalib seseorang bukan 'İsā, dan mereka menyangka itu adalah 'İsā 'Alayhi al-Salām padahal orang tersebut telah diserupakan dengan 'İsā, dan Allah telah mengangkat 'Īsā dalam keadaan hidup.

Riwayat ini tergolong dalam hadith Maqtū'. Ada rawī dalam riwayat ini yang dinilai sebagai mudallis yakni Ibn Abī Najịh. Terdapat riwayat lain yang menguatkan hal ini diriwayatkan Al-Tabarī dalam Tafsirnya dengan sanad yang berbeda tapi masih dari jalur yang sama dari Mujāhid. Lihat al-Ṭabarī Jāmi' al-Bayān fì Ta'wīl al-Qur'an, 9 : 374.

Ada satu riwayat yang menjelaskan bahwa 'Īsā diangkat pada umur tiga puluh tiga tahun sebagaimana yang dijelaskan Muqātil diriwayatkan oleh Ibn Ab̄̄ Ḥātim, sebagai berikut:

\footnotetext{
${ }^{75}$ Abū al-Hajjāj Mujāhid bin Jabr, Tafsīr Mujāhid (Mesir: Dar al-Fikr, 1989), hlm. 296.
} 


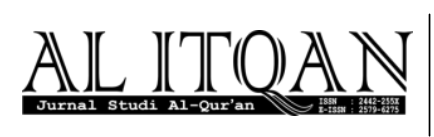

Melacak Sumber dan Keotentikan Penafsiran Muqātil bin Sulaymān Ahmad Jauhari Umam

Doi: doi.org/10.47454/itqan.v5i1. 710

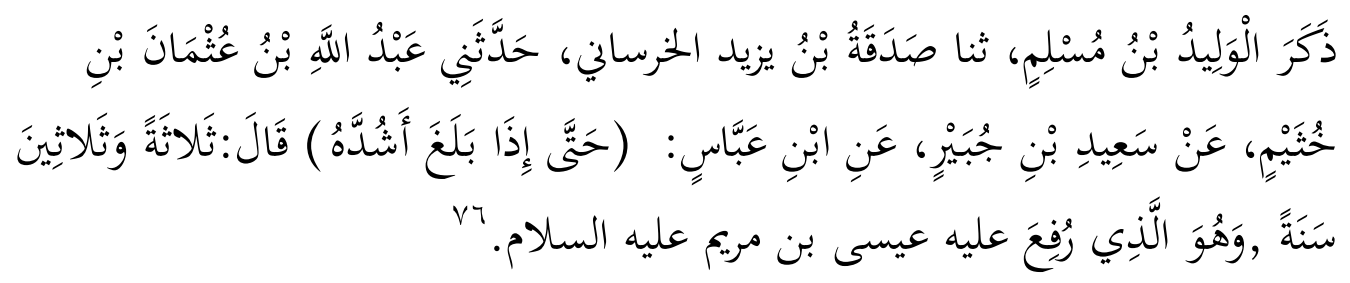

Al-Walīd bin Muslim menyebutkan telah mengabarkan kepada kami Șadaqah bin Yaz̄ì al-Khurasān̄̄ mengabarkan kepadaku Abdullah bin Uthmān bin Khuthaym dari Sa'īd bin Jubaīr dari Ibn 'Abbās "sehingga apabila dia telah dewasa" ia berkata: tiga puluh tiga tahun, dan itu adalah usia dimana Isa diangkat ke langit.

Riwayat ini tergolong dalam hadith Mauqū $f$ karena disandarkan kepada Sahabat. Riwayat ini daîf karena pada riwayat ini ada rawī yang dianggap sebagai seorang Mudallisyakni al-Walīd bin Muslim. Ada riwayat lain yang mendukung riwayat ini diriwayatkan oleh al-Ḥākim dari Wahb, al-Ḥākim dari jalur Saīd ibn Musayyib, dan diriwayatkan oleh Ibn Sa'ad dan Ahmad dalam al-Zuhd. Lihat al-Dur al-Manthūr, 2 : 226. Sehingga antara satu riwayat dengan riwayat lain saling menguatkan.

\section{Kesimpulan}

Dari penafsiran Surat Āli Imrān ayat 54-55 dan Surat al-Nisā’ ayat 157-158, Muqātil bin Sulayman menjelaskan bahwa yang disalib bukanlah 'İsā akan tetapi orang yang diserupakan dengannya yang bernama Yahūẓā, sedangkan 'Îsā disucikan dari kaum Yahudi dengan cara diangkat oleh Allah ke langit dunia dari Bait al-Maqdis pada malam Lailatu alQadr bulan Ramadhan diusia tiga puluh tiga tahun. Secara keseluruhan Muqātil tidak menyebutkan sumber-sumber penafsirannya secara jelas, dan setelah melalui proses pelacakan ditemukan pada Surat Āli Imrān ayat 54 terdapat tiga riwayat hadith, dua riwayat hadith Mauqūf dengan sanad yang Sahīḥ dan satu riwayat hadith Mursal da 'îf, pada Surat Āli Imrān ayat 55 ditemukan dua riwayat, satu riwayat hadith Mauqū $f$ dengan sanad Hasan dan satu riwayat ḍa 'îf. Pada Surat al-Nisā' ayat 157 ditemukan sumber Isrā '̄lliyyāt dan pada Surat al-Nisā' ayat 158 ditemukan dua riwayat, satu riwayat hadith Maqtū' dan satu riwayat hadith Mauqūf keduanya sama-sama dikuatkan oleh riwayat lainnya.

Dengan menggunakan teori Takhrīj Hadith dan teori al-Așil wa al-Dakhīl fì al-Tafsir penulis menemukan dari delapan riwayat diatas enam masuk kategori al-Așil fi al-Tafsir dan

\footnotetext{
${ }^{76}$ Muhammad Abdurrahman bin Muhammad bin Idris al-Rāzī Ibn Abī Hātim, Tafsīr al-Qur'an al- 'Ażìm li Ibn Abì Hătim, vol. 4, hlm. 1111.
} 
Melacak Sumber dan Keotentikan Penafsiran Muqātil bin Sulaymān Ahmad Jauhari Umam

Doi: doi.org/10.47454/itqan.v5i1.710

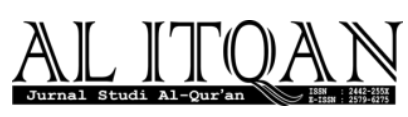

dua masuk kategori al-Dakhīl fì al-Tafsir yaitu riwayat yang Mursal dan riwayat yang da 'îf, sedangkan riwayat lainnya masuk dalam al-Așil fi al-Tafsir. Memang dalam hal ini mayoritas dari sumber penafsiran Muqātil adalah al-Așil fì al-Tafsir karena telah dilakukan pelacakan dan muqaranah dengan literatur lain, jika tidak maka akan terlihat da' $\urcorner f$ karena sumbersumber penafsirannya tidak diketahui dengan jelas. 


\section{DAFTAR PUSTAKA}

Asqalānī (al), Ahmad bin 'Alī bin Muhammad bin Ahmad bin Ḥajar. Tahdhīb al-Tahdhīb, India: Matba'ah Dairah al-Ma'arif al-Nizamiyah, 1905.

Abbās, Abdullah Ibn dikumpulkan oleh Muhammad bin Ya'qūb al-Fairūzābadī. Tanwīr alMiqbās min Tafsir Ibn Abbās, Beirut: Dar al-Kutub al-Ilmiyah, t.th.

Ahmad, Riqza. MindMap Al-Qur'an \& Ulum AL-Qur'an, Kudus: Mubarokatan Thoyyibah, 2019.

Baghdādī (al), Abū Bakar Ahmad bin 'Alī al-Khațīb. Tārīkhu Baghdād, Beirut: Dar al-Gharbi al-Islami, 2002.

Bāz (al), Muhammad Abbās. Mabāhith fì 'Ilm Qirā'āt ma'a Bayāni Ușūli Riwāyah Hasfṣ Kairo: Dar al-Kalimah, 2004.

Daniel, Norman. "Christian-Muslim Polemics" dalam Lindsay Jones (ed.), Encyclopedia of Religion, New York: Thmson-Gale, 2003.

Dhahābī (al), Muhammad bin Ahmad bin Uthmān bin Qaymāz. Siyaru A'lāmi al-Nubalā', t.tp: Muassasah al-Risalah, 1985.

Dhahabī (al). Muhammad Husain. al-Tafsīr wa al-Mufassirūn, Kairo: Dar al-Hadith, 2005.

Ḥātim, Abū Muhammad Abd al-Rahman al-Rāzī Ibn Abī. Tafsīr al-Qur'n al- 'Az̄ìm li Ibn Abī Hātim, Saudi Arabia: Maktabah Nizar Mustafa al-Baz, 1999.

Hosen, Nadirsyah. Tafsir Al-Qur'an di Medsos, Yogyakarta: Bunyan, 2017.

Injil Barnabas terj. Husin Abu Bakar Alhabsyi dan Abu Bakar Basymeleh, Surabaya: Mutiara Ilmu, 1996.

Ismā'̄il, Muhammad Ahmad. Tafsir al-Qur'an al-Karìm, Durus Sautiyah Qam bi Tafri'iha Mauqi al-Shubkah al-Islamiyah dalam http://www.islamweb.net, diakses pada Jabr, Abū al-Ḥajjāj Mujāhid bin. Tafsīr Mujāhid, Mesir: Dar al-Fikr, 1989.

Johns, A.H. "Muqatil B. Sulayman”, dalam Oliver Leaman (ed.), The Qur'an: an Encyclopedia, London dan New York: Routledge, 2006.

Kathīr, Ismā’̄il bin Umar bin. Tafsir al-Qur'an al- 'Ażīm, t.tp: Dar Ṭayyibah li Nashr wa alTauzi', 1999. 
Melacak Sumber dan Keotentikan Penafsiran Muqātil bin Sulaymān

Ahmad Jauhari Umam

Doi: doi.org/10.47454/itqan.v5i1.710

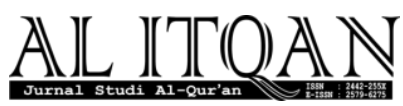

Ma'rifat, Muhammad Hadi. Kisah-Kisah Al-Qur'an Antara Fakta dan Metafora terj. Azam

Bahtiar, t.tp: Citra, 2013.

Mizzī (al) Jamāluddin bin al-Zakī Abī Muhammad al-Qađ̣ā'̄̄. Tahdhīb al-Kamāl fì Asmāi alRijāl, Beirut: Mua'assasah al-Risalah.

Naisābūrī (al), Abū Abdullah al-Ḥākim Muhammad. al-Mustadrak 'alā al-Ṣahīhain, Beirut: Mustafa Abd al-Qadir 'Ata, 1990.

Nasyirudin, Muhammad. "Kematian dan Penyaliban Nabi Isa AS dalam Tafsir Al-Manar", (Skripsi di UIN Sunan Kalijaga, 2016)

Rāzī (al), Abū Abdullah Fakruddin. Mafātīḥ al-Ghaybi, Beirut: Dar Ihya’ Turath, 1999.

Riḍā, Muhammad Rashid. Tafsīr al-Qur'an al-Karìm, Mesir: Hai’ah al-Misriyah al-'Ammah li al-Kitab, 1990.

Șallabi (al) Ali Muhammad. Isa bin Maryam Kelahiran, Kerasulan, Kisah Penyaliban hingga Turunnya Kembali di Akhir Zaman, Jakarta: Ummul Qura, 2020.

Sholihah, Afrohul Banat dan Siti Amilatus. "Pandangan Muqātil bin Sulaymān al-Balkhī (w. 150 H/767 M) tentang Muḥkamāt dan Mutashābihāt". Al-Itqān Jurnal Studi AlQur'an, vol.3, No.1(2017). (https://doi.org/10.47454/itqan.v3i1.32).

Sirry, Mun'im. "Muqatil b. Sulaymān and Anthropomorphism”. Studia Islamica, vol. 107, no. 1(2012) (https://doi.org/10.1163/19585705-12341235).

Sulaymān Muqātil bin, al-Wujūh wa al-Nazāîr fì al-Qur'an al-'Azīim, Riyad: Maktabah alRushd, 2011.

Sulaymān, Muqātil bin. Tafsīr Muqātil bin Sulaymān, Beirut: Mu'assasah al-Tārīkh al-'Arabi, 2002.

Suyūṭī (al), Jalāluddīn Abd al-Rahman bin Abi Bakar. al-Itqān fì Ulūm al-Qur'an Beirut: Dar al-Kutub Ilmiyah, 2018.

Suyūṭī Jalāl al-Dīn Abdurrahman, al-Dur al-Manthūr, Beirut: Dar al-Fikr, t.th.

Ṭabarī (al), Muhammad bin Jarīr. Jāmi' al-Bayān fì Ta'wīl al-Qur'an, t.tp: Mu'assasah alRisalah, 2000.

Tūnisī (al), Muhammad al-Ṭāhir bin 'Āshūr. al-Tahrī̄r wa al-Tanwīr min Tafsīr al-Kitāb alMajīd, Tunisia: al-Dar al-Tunisiyah li Nashr, 1984. 


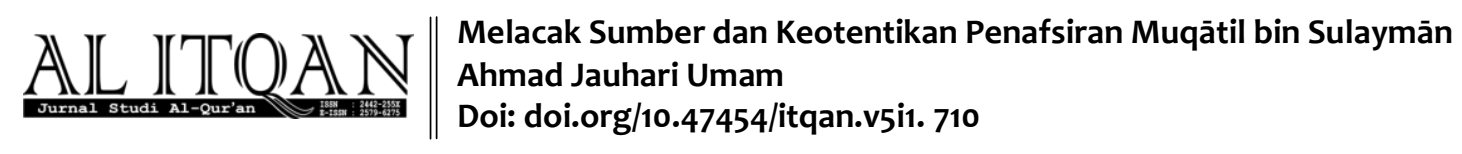

Umam, Muhammad Fithri. "Telaah Kritis terhadap Periodesasi Kodifikasi Muhammad Husyn al-Dhahabi dalam al-Tafsir wa al-Mufassirun". Al-Itqān Jurnal Studi Al-Qur'an vol. 2, no. 2(2016). (https://doi.org/10.47454/itqan.v1i1.12).

Versteegh, Kees. "Tafsir Quran Paling Awal: Tafsir Muqātil”, (Makalah yang disampaikan di Universitas Leiden pada 3 November 1988). 